\title{
Türkiye Ekonomisinde Geç Kalkınmanın ve Yerli Üretimin Ekonomi Politiği ${ }^{1}$
}

\author{
The Political Economy of Late Development and Domestic Production in Turkish \\ Economy
}

Murad TIRYAKIOĞLU

\begin{abstract}
ÖZET
Kalkınma ekonomisi yazını İngiltere'nin başlattığı Sanayi Devrimini yakalayamayan ülkeleri geç kalkınan ülkeler olarak tanımlamaktadır. İkinci kuşak sanayi devrimi ile kalkınma yolunda önemli adımlar atan Almanya, Japonya gibi ülkeleri geç kalkınan ülkeler olarak tanımlayan literatür, Asya Kaplanları olarak da adlandırılan Güney Kore, Tayvan, Hong Kong ve Singapur'u ise geç-geç kalkınan ülkeler olarak sınıflandırmaktadır. Bu gelişim sürecinde, Türkiye açısından sorulması gereken en önemli soru "Türkiye'nin gelecekte, küresel ekonomide nerede ve daha önemlisi nasıl bir konum alacağı"dır. Yaklaşık on bin dolarlık bir gelir düzeyi ile orta gelir tuzağına yakalanmış olmasına karşın coğrafi konumu, genç nüfusu, yerli üretim konusunda gösterdiği çabalar göz önünde bulundurulduğunda yükselen ekonomiler arasında anılmaya başlamıştır. Çalışma, geç kalkınan ve geç-geç kalkınan ülkelerin tecrübelerinden yola çıkılarak Türkiye'nin birlikte anıldığı MINT, MIKTA ve N-11 gibi yükselen ülke ekonomileri arasından özellikle yerli üretim beceri ve tecrübeleri bakımından ayrışma ihtimalini sorgulamakta ve bu kapsamda nasıl bir ekonomipolitiğe sahip olması gerektiğini tartışmaktadır.
\end{abstract}

Anahtar Kelimeler: Geç-Kalkınma, Yerli Üretim, Teknolojik Öğrenme, Yükselen Ekonomiler

\begin{abstract}
The literature of development economics describes the countries that failed to catch up with the Industrial Revolution, which began in England, as late developed countries. Some countries such as Germany and Japan which have taken significant steps towards development through second generation industrial revolution are characterized as the late developed countries by literature. On the other hand, South Korea, Taiwan, Hong Kong and Singapore, also known as the Asian Tigers, are classified as late-late developed countries. During this development process, the most important questions to be directed to Turkey are that "Where will the exact position of Turkey be in the future?" and maybe more importantly "How will Turkey take a position in the global economy?" Although Turkey has been caught by the middle income trap with its nearly ten thousand dollars of income, Turkey has begun to be known among the emerging economies considering her geographical location, young population and efforts on domestic production. The study intends to investigate the probability of dissociation of Turkey from the emerging countries such as MINT, MIKTA and N-11 with which Turkey is also associated in terms of its domestic production capability and experience by starting to make use of the experience of the late developed and late-late developed countries, and it also discusses to what extent the country needs to have economics policy in this regard.
\end{abstract}

Keywords: Late-Development, Domestic Production, Technological Learning, Emerging Economies

\section{Dr. Afyon Kocatepe Üniversitesi, murad@tiryakioglu.org}

'Bu çalışma, yazarın birbirinin tamamlayıcısı niteliğinde olan “Yerli Üretim Tartışmaları Işığında Türkiye'nin Geç Sanayileşme Çabalarına iliş̧kin Bir Değerlendirme" [Third International Conference on Economics, The Turkish Economic Assosiation, November 1-3, 2012, İzmir, Türkiye] ve "Türkiye'de Geç Sanayileşmenin Ekonomi-Politiği: Yerli Üretim Kapasitesine ve Potansiyeline illişkin Bir Tartışma" [Ulusal Üretim Ekonomisi Kongresi, 21-22 Mart 2014, İstanbul, Türkiye] başlıklı çalışmalarının geliştirilerek bir araya getirilmiş halidir.

Yazar titiz değerlendirmeleri ve çalışmanın daha nitelikli hale gelmesi için sundukları öneriler için editör ve hakemlere teşekkür eder. 


\section{GíRiş}

Dünya ekonomisinin gelişme sürecine bakıldığında teknolojik yetenek transferi ve öğrenmenin başat bir rol oynadığı görülmektedir. Öğrenme sürecini belirgin bir biçimde örnekleyen ülkeler geç kalkınan ve geç-geç kalkınan ülkeler olarak sınıflandırılmaktadır. Kalkınma ekonomisi yazını, Sanayi Devriminin ardından İngiltere'yi yakalamaya çalışan Almanya, Rusya ve Japonya'yı geç-kalkınan ülkeler (Gerschenkorn, 1962), üçüncü kuşak sanayi devrimi ile öncekileri yakalama başarısı gösteren Güney Kore, Tayvan, Hong Kong ve Singapur'u ise geç-geç kalkınan ülkeler (Vogel, 1991) olarak tanımlamaktadır. Birbirini takip eden ve öncekileri yakalama başarısı gösteren bu ülke gruplarına günümüz dünyasında BRICS, MINT, MIKTA ve N-11 gibi ülke gruplarının², üçüncü nesil geç kalkınan ülkeler ${ }^{3}$ olarak eklemlenip eklemlenemeyeceği tartışılmaktadır.

Birbirini takip eden ve yakalama başarısı ile rekabetçiliğini arttıran ülkelerin tecrübeleri tarihsel olarak incelendiğinde, ortaya çıkan ortak sonuç, her birinin teknolojik yetenek transferi gerçekleştirerek öğrenme ve adaptasyon odaklı bir politikalar bütünü izlemiş olmalarıdır. Yerli ve yenilikçi üretim kapasite ve yetenekleri devlet tarafından desteklenen, öğrenme temelli teknoloji transferi politikaları ile şekillendirilmiş ve geliştirilmiştir. Sanayileşme sürecinde devlet müdahalesi olmadan yoluna devam eden hiçbir ülke olmadığı için devlet müdahaleciliğini azımsama veya müdahalecilikten vazgeçme gibi bir alternatif sözkonusu değildir. Bu çerçevede tasarlanan çalışma kapsamında, Türkiye'ye ilişkin bir değerlendirme yapabilmek için Dünya'da yerli üretim yeteneklerini geliştiren ülkelerin geç kalkınma tecrübeleri incelenerek Türkiye özelinde bir tartışma çerçevesi oluşturulmaktadır. Bu tartışma kapsamında 'yerli üretim' ile kastedilen tamamen ülke içinde üretilen ürünler ile üretim sürecinin önemli aşamalarının ve iktisadi açıdan gerek duyulan tasarım ve işçilik süreçlerinin ülke içinde gerçekleştirilmiş olmasıdır. Bu çerçeve üretimin ithalata bağımlılığının düşük olması, üretimde kullanılan girdilerin ve ara malların da benzer şekilde Türkiye'de üretiliyor, tasarımının ve işçilik süreçlerinin Türkiye'de gerçekleştiriliyor olmasını da kapsamaktadır.

Çalışma temel olarak geç kalkınma başarısı yakalayan ülkelerin tecrübelerinden yola çıkarak MINT, MIKTA ve N-11 grubunda anılan Türkiye'de geç kalkınmanın nasıl bir ekonomi-politik çerçevesinde şekillendirilmesi gerektiği tartışmaktadır. Bu tartışma kapsamında sanayileşme, kalkınmanın bir boyutu olarak ele alınmakta ve orta ve yüksek teknolojiye dayalı yerli üretim odaklı sanayileşme politikasının önemi ele alınmaktadır. Türkiye, yaklaşık on bin dolarlık gelir düzeyi ile orta gelir tuzağına yakalanmış olmasına karşın coğrafi konumu, genç nüfusu, yerli üretim konusunda gösterdiği çabalar göz önünde bulundurulduğunda yükselen ekonomiler arasında anılmaya başlamıştır. 1924 yılında (Yunanlılardan savaş ganimeti olarak toplanan parçalardan) yapılan ilk Türk Uçağı Vecihi K-6; 1960 yılında ilk yerli motoru Gümüş Motor; 1961 yılında ilk yerli otomobil olan Devrim, 1970'li yıllarda üretilen ilk yerli bilgisayarları Uslu ve Boncuk ve 1990'lı yıllarda üretilen ilk yerli cep telefonu Aselsan-1919 yerli üretim yeteneklerinin Cumhuriyetin ilk yıllarından başlayarak geliştiğini göstermektedir. 2000'li yıllarda ise, özellikle savunma sanayii alanında ilk denemeleri başarı ile yapılan yerli savaş gemisi Milgem, yerli tank Altay, yerli insansız hava aracı Anka ve yerli eğitim uçağı Hürkuş ile yerli üretim kapasite ve yeteneklerinin gelişmeye devam ettiğini göstermektedir. Bu tecrübelerden yola çıkılarak tasarlanan ve Türkçe literatüre önemli bir katkı niteliği taşıyan bu çalışmada, seçilmiş örneklerin başarıları, Türkiye'de yerli üretimin yeteneklerinin gelişimi ve nihayet Türkiye'nin nerede konumlanacağı tartışılmaktadır. Çalışmanın özgün değerini, yerli üretim tartışmalarını bütüncül bir yaklaşım ile tarihsel tecrübeler, iyi örnekler ve gelecek tartışmaları çerçevesinde ele alması oluşturmaktadır. Yerli üretimin stratejik önemine odaklanmış bu çalışmanın, girişi takip eden ikinci bölümünde geç ve geç-geç kalkınma yazınına, birinci ve ikinci nesil geç kalkınan ülke tecrübelerine yer verilmektedir. Üçüncü bölümde ise Türkiye'nin yerli üretim ve sanayileşme çabaları tarihsel gelişim süreci içinde ele alınarak kalkınmacı devletin rolünün yeniden tanımlanması

\footnotetext{
2'BRICS: Brezilya, Rusya, Hindistan, Çin; MINT: Meksika, Endonezya, Nijerya, Türkiye; MIKTA: Meksika, Endonezya, Güney Kore, Türkiye, Avustralya; N-11: Bangladeş, Endonezya, Filipinler, Güney Kore, İran, Meksika, Mısır, Nijerya, Pakistan, Türkiye, Vietnam. Bu sayılan ülke gruplarına Meksika, Endonezya, Güney Kore, Türkiye ve Avusturalya'dan oluşan MIKTA ve Endonezya, Güney Kore, Avusturalya, Meksika, Türkiye, Arjantin ve Suudi Arabistan'dan oluşan Orta-7 de ilave edilebilir. MIKTA ve M-7, 2007-2010 yılları arasında ve son olarak 2013 yılında Avustralya Başbakanlığı ve 2010-2012 yılları arasında Avustralya Dışişleri Bakanlığı yapmış olan Kevin Rudd tarafından şekillendirilmiştir. G-20 ve orta ölçekli devletlerin küresel ekonomi yönetimindeki önemi üzerine bir tartışma için bakınız: Rudd, 2015. MIKTA hakkında tanımlayıcı bir bilgi notu ve potansiyel tartışma alanları için bakınız: Karagöl, 2014.

${ }^{3}$ Çalışmada geç kalkınan ülkeler 'birinci nesil geç kalkınan ülkeler', geç-geç kalkınan ülkeler 'ikinci nesil geç-kalkınan ülkeler' ve potansiyel olarak geriden gelecek ve yakalama başarısı gösterecek ülkeler de 'üçüncü nesil geç kalkınan ülkeler' olarak anılacaktır. 
gerektiği ve odaklanmış bir yerli üretim hedefinin yükselen Türkiye ekonomisinin muhtemel yoksulluk tuzaklarını bertaraf edebilmesi için öncelikli hedef olarak belirlenmesi gerektiğinin altı çizilmektedir. Son başlık ise Türkiye'de geç kalkınmanın ve yerli üretimin ekonomi politiği şekillendirilirken hangi soru(n)ların göz önünde bulundurulması gerektiği ele alınmaktadır.

\section{GEÇ KALKINMA TECRÜBELERi}

Her geçen gün gelişen ve yeniden şekillenmeye devam eden kalkınma iktisadı literatürüne göre, İngilteresnin öncülük ettiği Sanayi Devrimi, Batı Avrupa, Kuzey Amerika ve ardından da Japonya'yı içine alacak şekilde genişlemiştir. Kıta Avrupası'nda Almanya ve Rusya, Uzakdoğu'da ise Japonya gibi ülkeler ikinci sanayi devrimini yaşamış ve iktisadi kalkınma literatürüne 'geç kalkınan' ülkeler olarak geçmiştir (Gerschenkron, 1962). Yüksek yatırım maliyetlerini üstlenecek finansman kuruluşlarının önemine dikkat çeken Gerschenkron (1962), eğer finansman konusunda toplumsal yeterlilik varsa geç gelenlerin, ilk yenilik yapanlara göre çok daha ucuz ve kolay bir biçimde transfer edilebilecek teknolojilerin ve becerilerin getireceği avantajlardan yararlanacağına işaret etmektedir.Yabancı teknolojiler ve bunların uluslararasında yayılmasının önemi, hem Avrupa'nın hem de ABD'nin on dokuzuncu yüzyıldaki sanayileşmelerinde ve daha da çarpıcı bir biçimde, Japonya'nın yirminci yüzyıldaki sanayileşmesinde çok iyi bilinen faktörler olarak ifade edilmektedir. $\mathrm{Bu}$ faktörlerin önemi, günümüzde dinamik Asya ekonomileri olarak da adlandırılan Güney Kore, Tayvan, Singapur ve son zamanlarda da Çin, Malezya, Tayland ve Endonezya'nın hızlı sanayileşmesi ile daha da güçlü bir şekilde kanıtlanmaktadır (Freeman ve Soete, 1997:351). Bu tarihsel gelişim sürecinde yirmi birinci yüzyılın kalkınan ekonomilerinin hangileri olacağı ve bu potansiyel adayların BRICS, MINT, MIKTA ve N-11 gibi ülke grupları arasından çıkıp çıkamayacağı güncel tartışma konularından birini oluşturmaktadır.

Tarihsel olarak geç ve geç-geç kalkınma örnekleri incelendiğinde kamu politikalarının belirleyici rolü ön plana çıkmaktadır. Rosenstein-Rodan (1943), kamu müdahalesinin etkin ve belirleyici olduğu sanayileşme stratejisi üzerinde durmakta ve birinci sanayi devrimini kaçıran ülkelerin sanayileşme süreçlerini hızlandırmak amacıyla kamu sektörünün politikalar geliştirmesi gerektiği fikrini savunmaktadır. Birinci nesil geç kalkınan Japonya ve Almanya gibi ülkelerin 19. yüzyılın ikinci yarısındaki ilk kalkınma dönemlerinde kamu politikalarının (Yülek 1998), bir diğer anlamda Johnson'un (1982) kavramsallaştırdığı kalkınmacı devletin önemli rolü olmuştur. Bebek sanayi korumasının anavatanı olarak kabul edilen Almanya, birinci sanayi devrimine öncülük eden İngiltere'yi yakalamaya çalışan ve geç kalkınma başarısı gösteren ülkelerden biri olarak anılmaktadır. List (1841) tarafından bebek sanayiyi koruma tezi olarak kavramsallaştırılan korumacılık, Amerika Birleşik Devletleri'nin ve İngiltere'nin kalkınmasında, Almanya'ya oranla daha belirgin bir rol oynamıştır. Chang'a (2009:53) göre, gerçekte birçoklarının sandığı gibi bebek sanayi argümanı, sistematik bir biçimde ilk kez Friedrich List'in eserlerinde değil, Hamilton'un 'İmalât Konusundaki Hazine Sekreterinin Raporları'nda ortaya konmuştur. Chang (2009:17-18), bugünün kalkınmış ülkelerinin bulundukları konuma, kalkınmakta olan ülkelere tavsiye ettikleri politika ve kurumlarla gelmemiş olduğunu, Dünya Ticaret Örgütü tarafından benimsenmeyen bebek sanayi koruması ve ihracat teşvikleri gibi 'yanlış'(!) ticaret ve sanayi politikaları uyguladıklarını ifade etmektedir. Chang ve Grabel (2004:19-27), kalkınmanın yeniden tartışılması gerektiğini iddia ettikleri çalışmalarında, "günümüzün zengin ülkelerinin serbest piyasaya kararlı bir bağlılık göstererek başarıya ulaştığı" söyleminin gerçekliğini öncelikle ele almakta ve tartışmaktadır. Bu kapsamda, bugünün sanayileşmiş ülkelerinin, serbest piyasa politikalarına kararlı bağlılıkları sayesinde büyüyüp zenginleştiklerine, devlet müdahaleciliğinin kalkınma yolunda başarısızlığa sebep olduğuna ilişkin söylemleri geçersiz kılan örnekleri, yine bugünün sanayileşmiş ülkelerinin oluşturduğunu vurgulamaktadır ${ }^{4}$.

\section{Almanya'da Geç Kalkınma, Teknolojik Öğrenme} ve Sanayileşme: On dokuzuncu yüzyılın ilk döneminde başlayan Almanya'nın geç sanayileşme ve öğrenme süreci, devlet destekli sanayi casusluğuna, 
yurt dışından kalifiye işçilerin getirilmesine ve özellikle Britanya'dan ve diğer kalkınmış ülkelerden ileri teknoloji transferi sağlanmasına dayanmaktadır. Aynı dönemde, yeni teknolojilerle ilgili bilgi edinmek amacıyla düzenlenen geziler desteklenmiş, kopyalanması amacıyla makineler ithal edilmiş ve yetenekli işçileri yetiştirmek amacıyla ustalık enstitüleri (Gewerbeinstitut) kurulmuştur. $\mathrm{Bu}$ kapsamda şekillendirilen devlet anlayışı teknoloji transferinden sağlanacak öğrenmenin geç sanayileşme için önemine işaret etmektedir (Chang, 2009:69). Almanya'da 1870'lerden başlayarak, ekonomiye katılan mühendislerin sayısını büyük ölçüde arttırıp niteliklerini de iyileştiren yeni yükseköğretim kurumları kurulmuş ve ülkedeki finansal kurumlar yapılarını ve politikalarını, büyük ölçekteki yeni teknolojik gelişmelerin finansman gereksinimlerine uyarlamıştır. Bunun sonucu olarak ülkenin beşeri ve teknolojik altyapısı güçlenmiş, çelik ve elektrik sanayinde büyük firmalar gelişmiştir (Freeman ve Louça, 2013:323). Ayrıca bu teknolojik gelişim sürecinde motor endüstrisindeki gelişmeler ülkede otomotiv sanayinin oluşumunu ve gelişimi sağlamış, Nikolaus Otto (1832- 1891), Gottlieb Daimler (1834-1900), William Maybach (1846-1929) ve Karl-Friedrich Benz (1844-1929) gibi Alman mucitler günümüzün önemli otomotiv sanayisinin teknolojik temellerinin atılmasında ve küresel markalarının gelişiminde önemli rol oynamışlardır (Özilgen, 2011:187-188).

Yabancı sermaye ve teknoloji girişinin teşvik edilmesinin yanısıra nitelikli yabancı emeğin hizmetinden geniş çapta yararlanması üzerine tasarlanmış emek transferi de Alman sanayileşmesinin hızlandırılmasında önemli rol oynamıştır (Ballance vd., 1985:13-18). Tüm bu faktörlerin sanayileşmeye yönelik bir girişim içinde yapılandırılmasında ve organize edilmesinde devlet belirleyici olmuştur. Her ne kadar 1840'lardan sonra, özel sektörün büyümesiyle Alman devletinin sınaî büyümeye katkısı azalmış ve yönlendirici rolünden vazgeçerek yol gösterici bir rol üstlenmişse de (Chang, 2009:71) özellikle ağır sanayide devletin rolü hayati bir öneme sahipti (Ballance vd., 1985:25). Almanya'nın beşeri sermaye ve teknik bilgi birikimine yönelik eğitim altyapısını çok güçlü bir şekilde yapılandırmasını sağlayan faktörler, yüksek standartlardaki eğitim sistemi ve bilim ve teknolojiye yönelik devlet politikaları olarak ifade edilebilir.

Japonya'da Geç Kalkınma, Teknolojik Öğrenme ve Sanayileşme: Japonya, hem transfer ettiği teknolojiden öğrenme sağlayarak üstün teknolojik yeteneklere sahip olmayı başarabilen bir ülke olması itibariyle hem de geriden gelen Doğu Asya ülkelerinin sanayileşme politikalarında ve yakalama başarılarında etkili ve yönlendirici olması itibariyle özel bir öneme sahiptir. Japonya'nın izlediği geçkalkınma modelinin en önemli unsurlarından birisi gelişmiş ülkeler ile arasındaki teknolojik açığı kapatma temeline dayanıyor olmasıdır. Bu süreçte kopya teknolojiler, tersine mühendislik yöntemleri gibi teknoloji transferi kanalları, klasik Ar-Ge teşviklerinin en önemli tamamlayıcısı olarak kullanılmıştır. Bununla birlikte teknoloji transferini sağlayan yabancı sermaye yatırımlarına ilişkin sınırlama ve denetleme mekanizması da teknolojik öğrenme ve gelişme sürecini belirleyen, etkinliğini arttıran bir diğer faktör olarak bu modelin önemli unsurlarından birini oluşturmuştur.

Japon kalkınma modeli, "Uçan Kaz Modeli"5 ile açıklanmaktadır. Akamatsu $(1961,1962)$ tarafından geliştirilen bu modelin temel iddiası, öncü bir gelişmiş ülkenin geçirdiği yapısal dönüşümleri zamanla onu takip eden ülkelerin de aşamalı olarak geçireceğidir. Model, lider ülkenin emek-yoğun sektörlerden sermaye-yoğun sektörlere ve üretime geçişi üzerine kurulmuştur. Modele göre, takipçi ülke ilk aşamada ana mallarını ihraç, sanayi mallarını ithal etmektedir. İkinci aşama ithal edilen malların yerli üretiminin başlamasını içermektedir. Üçüncü aşamada yerli üretimi gerçekleştirilen malların ihracı başlatılırken son aşamada ise sermaye malları üretimi de yerli üretime dahil edilir (Akamatsu, 1962:1215). Japonya'nın Asya Kaplanları ve özellikle de Güney Kore ile arasındaki ilişki bu şekilde değerlendirilmektedir.

Öğrenme temelli teknoloji transferi sürecini, etkin sanayi, teknoloji ve ticaret politikalarıyla tamamlayan ve kalkınmacı devletin kontrolünde sınaî altyapının oluşumunu ve gelişimini sağlayan Japonya, birinci nesil geriden gelen ülkeler arasında öne çıkmakla kalmamış aynı zamanda Doğu Asya ülkeleri için de model oluşturmuştur ${ }^{6}$.

${ }^{5}$ Uçan Kaz Modeli ilk kez 1930'lu yıllarda Kaname Akamatsu'nun Japonca yayımlanan iki çalışmasına dayanmaktadır. Bu çalışmalar 1961 ve 1962 yıllarında İngilizce olarak yeniden yayımlanmıştır. İlgili çalışmalar için bakınız: Akamatsu, Kaname (1961). "A Theory Of Unbalanced Growth in the World Economy" Weltwirtschaftliches Archiv, 86: 196-217.; Akamatsu, Kaname (1962). "A Historical Pattern of Economic Growth in Developing Countries", Journal of Developing Economies, 1(1):3-25.

${ }^{6}$ Chang (2009:95) devletin uyguladığı etkin politikalara ilişkin World Bank (1993); Singh (1994); Lall (1994); Stiglitz (1996); Wade (1996) gibi çalışmalara atıfla kalkınmacı devlet anlayışının önemini vurgulamaktadır. 
Chang ve Grabel (2004:60-61), Doğu Asya modelinin başarısını (i) Doğu Asya ülkelerinin ortak bir Konfüçyüsçü kültüre sahip olması; (ii) mutabakat oluşturmayı ve politikaları uygulamayı kolaylaştıran bir unsur olarak etnik olarak gelişmekte olan diğer ülkelerin çoğundan çok daha homojen olmaları; (iii) doğal kaynaklar açısından yaşadıkları yoksulluğu imalât yoluyla servet birikimine dönüştürmek motivasyonuna dönüştürmeleri; (iv) Japon sömürgeciliğinin geride güçlü bir sanayi temeli, eğitilmiş bir nüfus ve gelişmiş bir altyapı bırakmasına ve nihayet (v) Doğu Asya ülkelerinin 1980'lere kadar 'müsamahalı'7 bir uluslararası politik ortamdan faydalanmaları ile açıklamaktadır. Tüm bu faktörleri tamamlayıcı nitelikte, devletin çok önemli ve aynı oranda belirleyici rol oynamış olduğu konusunda bir fikir birliği söz konusudur.

\section{Güney Kore'de Geç-Geç Kalkınma, Teknolojik Öğrenme ve Sanayileşme ${ }^{8}$ :}

Yeni teknoloji edinimi, kullanımı ve geliştirilmesi yönündeki genel beceri ve eğilimi sayesinde Doğu Asya ülkeleri arasında farklı bir yerde konumlanan Güney Kore, kısıtlı kaynaklara sahip bir ülke olarak 1960'lı yılların başında, sanayileşme için gereken sermaye birikimine ve teknolojiye sahip değildi. Bu sebeple dışa bağımlı-yabancı kaynaklara, sermayeye, pazarlara ve teknolojilere dayalı bir kalkınma stratejisini tercih etmek zorunda kalmıştır. Bu süreçte, hafif sanayinin gelişimi için teknolojik öğrenmenin yoğun olarak kullanıldığı ve zamanla ağır makine ve kimya sanayinin gelişimine odaklanmış bir politika izlenmiştir (Suh, 2009:38-39). 1980'lerin başında başlatılan yerel Ar-Ge çabalarına ilişkin çalışmalar hem bilgi temelli kalkınma sürecine temel oluşturmuş hem de Güneydoğu Asya krizinin aşılmasında etkili olmuştur. Bu durum, Japonya örneğinde olduğu gibi, Güney Kore'nin geç kalkınma başarısının güçlü ve müdahaleci bir devlet anlayışına dayandığını göstermektedir.

Bellek çiplerinin üretim ve ihracatını, Japonya ve $A B D$ 'den sonra yapabilen üçüncü ülke olma başarısını gösteren Güney Kore, kısmen Amerikan elektronik sanayisinde faaliyet gösteren küçük ve orta ölçekli firmaların satın alınarak ortaklıklar kurulması ile, kısmen de Amerikan üniversitelerinden mezun öğrencilerle Amerikan firmalarında çalışmış olanların istihdam edilmesi ile bu başarıyı yakalamıştır (Freeman ve Soete, 1997:180). Güney Kore, bu stratejiyi uygularken yabancı teknolojilerin ülkeye transferinin desteklenmesi, transfer edilen teknolojilerin özümsenmesi ve geliştirilmesi için teknolojik yeteneklerin geliştirilmesi yönünde iki amaçla hareket etmiştir (Suh, 2009:40).

Güney Kore 1990'lı yıllardan sonra, özellikle Güney Doğu Asya krizinin ardından teknolojik yetenek kazanmak ve geliştirmek için ulusal Ar-Ge ve teknoloji faaliyetlerine ağırlık vermiştir. Bu sürecin en önemli aktörlerini ise şabol (chaebol) olarak adlandırılan firma yapılanmaları oluşturmaktadır. Hükümet tarafından yürütülen politikalara uyumlu bir şekilde faaliyet gösteren, büyük işletme ağları veya kümelenmeleri olarak tanımlanan ve ailelerin sahipliğinde olan bu firmalar, Güney Kore'nin bilgi temelli ekonomik dönüşümünde önemli rol oynamışlardır. Kriz sonrası dönemde dinamizmini kaybettiği gerekçesi ile yeniden yapılandırılan şaboller, teknolojik gelişme sürecinde önemli birer üretici birime dönüşmüşlerdir. Bu dönüşüm, kalkınmacı devlet anlayışının, kalkınma kararlılığının ve toplumsal motivasyonun bir sonucu olarak Güney Kore'yi uluslararası düzeyde rekabetçi bir ülke olma başarısına eriştirmiştir.

\section{Tayvan'da Geç-Geç Kalkınma, Teknolojik} Öğrenme ve Sanayileşme: Tayvan, Asya Kaplanları arasında sanayileşme ve kalkınma çabalarını başlatan ilk ülke olarak Japonya'nın öncülüğünden faydalanmıştır. Güney Kore'den farklı bir ekonomik yapılanma izleyerek küçük ölçekli, binlerce aile ve şahıs şirketinin oluşturduğu, dinamik ve esnek bir ekonomik yapı oluşturmuştur. Tayvan, bu dinamik ve esnek ekonominin ve uygulanan (ithâl ikâmeci ve sonrasında ihracata yönelik sanayileşme) politikaların etkisiyle batılı ulusların ve Japonya'nın bir yüzyıl ve daha uzun sürede tamamlayabildikleri sanayileşme ve kalkınma sürecini 40 yıl gibi bir sürede tamamlamayı başarmıştır (Kozlu, 2003:120-121). Bu hızlı sanayileşmeyi destekleyici bilim ve teknoloji politikaları sayesinde, teknoloji, yabancı yatırımlar aracılığı ile ülkeye transfer edilmiş ve öğrenilmesi sağlanmıştır. Tayvan'ın sanayileşme ve kalkınma

${ }^{7}$ Chang ve Grabel'e (2005) göre, Doğu Asya ülkelerinin merkantilist dış ticaret politikaları uygulamaları ve hatta büyüyüp zenginleşmek için sanayileşmiş ülkelere ait ticari marka ve patent haklarını ihlal ederek hileli yollara sapmaları hoş görülmüştü. Günümüzde ise, teşviklere ve fikri mülki haklara ilişkin Dünya Ticaret Örgütü kuralları, gelişmekte olan ülkelerin Doğu Asya modelinin en önemli öğelerini benimsemelerini ve uygulamalarını engellemektedir.

${ }^{8}$ Güney Kore ekonomisi, geç kalkınma literatürünün en kapsamlı biçimde incelediği örneklerden biri ve belki de en önemlisidir. Bu konuda yazılmış kapsamlı pek çok eser bulunuyorsa da bu çalışma kapsamında altı çizilebilecek kaynaklardan birkaçı şu şekilde sıralanabilir: Akkemik (2009); Amsden(1989); Chang (2009); Frank (2010); Koo (1984); Mah (2007); Suh (2009); Tiryakioğlu (2012); Tiryakioğlu (2015a); Vogel (1991); Wade (1990); Yülek (1998). 
tecrübelerinde, diğer geç kalkınan ülke örneklerinde olduğu gibi devlet belirleyici bir rol üstlenmektedir.

Tayvan'ın teknolojik öğrenme ve teknolojik yetenek birikiminde yabancı sermaye yatırımları ile ülkeye giren teknolojinin yanı sıra ileri teknoloji kullanan ve geliştiren küçük ve orta ölçekli firmaların özendirilmesi teknolojik gelişim sürecini hızlandırmıştır. Teknoloji transferinden öğrenme sağlayan Tavyan'da yerli şirketlerin güçlü olduğu alanlara yabancı sermaye yatırımlarının girişi engellenmiş ve bu şekilde yerel teknolojilerin yaygınlaşması sağlanmıştır. Denetimli olarak izin verilen yabancı sermaye yatırımlarından en yüksek düzeyde öğrenmeyi sağlamak için yerli Ar-Ge üretimi ve KOBi'lerin teknoloji düzeylerini yükseltmeleri için güçlü teknoloji desteği verilmiştir (Lall, 2009:485). Mathews (2002) Tayvan ekonomisinde sağlanan teknolojikyakalama veöğrenme başarısının en önemli aktörü olarak KOBI'leri işaret etmekte ve sağlanan bu desteğin teknolojik öğrenmeyi tamamlayıcı etkisini vurgulamaktadır.

Singapur'da Geç-Geç Kalkınma, Teknolojik Öğrenme ve Sanayileşme: Singapur'un geç kalkınma ve sanayileşme süreci ve sahip olduğu özellikler diğer ülke örneklerinden belli ölçüde ayrılmaktadır. 1963 yılında başlayan kalkınma sürecinin en önemli özelliği, Singapur'un beşeri ve fiziki imkânlardan tamamen yoksun bir ülke olarak, dışa açılma ve yabancı yatırımların imkânlarından azami ölçüde faydalanma becerisine dayalıdır. Ülkenin kalkınma hamlesini başlatan lider Li Kvanyev'in öncülüğünde geliştirilen kalkınma planları ileri düzeyde teknolojik yetenek birikimi sağlayacak teknik ve bilimsel eğitime, yaygın ve kaliteli bir İngilizce eğitimine, sağlık, ulaşım ve haberleşmenin güçlü bir altyapı ile oluşturulmasına ve çok iyi denetlenen, dünyaya açık bir bankacılık sistemine odaklanmıştır (Sönmez, 2003:215-216).
Singapur'un sınaî derinlik kazanmasında, korumacılık olmadan uzmanlaşma, yüksek vasıflı, ileri teknoloji sektörlerine destek sağlanması ve bununla beraber uluslararası firmalara yönelik ArGe hedefleri belirleyici olmuştur (Lall, 2009:485). Singapur'un teknolojik gelişme başarısının altında diğer ülke örneklerinden farklılaşan iki nokta dikkat çekmektedir: Birincisi korumacılığın olmaması, ikincisi ise yerli üretim ve kaynak kullanımının önceliklendirilmemiş olmasıdır. $\mathrm{Bu}$ süreçte hükümetin amacl, öğrenmeyi, teknoloji edinmeyi, sanayi merdivenini hızla tırmanmayı sağlayacak çalışan nüfusun niteliklerini ve gelirlerini en üst düzeye çıkartmak olmuştur (Lall, 2009:488). Yabancı yatırımcılar için başvuru ve değerlendirme süreci tek bir noktada toplanmış ve 'bir-adımda işlem' (onestep procedure) olarak adlandırılan sistem (Sönmez, 2003:216) Singapur'u yabancı yatırımcılar için cazibe merkezi haline getirmiştir.

Geç kalkınma tecrübeleri incelendiğinde görülmektedir ki, ulusal teknolojik yetenek ve yerli üretim kapasitesi, teknolojik öğrenme sürecine, yabancıkaynaklarınetkinbirşekildeyönlendirilmesine ve kullanılmasına ve nihayet devletin oynadığı kalkınmacı, girişimci, yenilikçi role bağlı olarak gelişmektedir. Dikkat çekici unsur, Japonya'nın açtığı yolda ilerleyen Doğu Asya ülkelerinin ve bu ülkelerden ayrışan Asya Kaplanları'nın uyguladığı sanayi, ticaret ve teknoloji politikaları, on sekizinci yüzyılda Britanya; on dokuzuncu yüzyılda $A B D$ ve yirminci yüzyılın başlarında Almanya ve İsveç gibi ülkelerin uyguladıkları politikalar ile büyük benzerlik göstermektedir. Ancak Doğu Asya ülkelerinin kendinden önce sanayileşmiş ülkelerin uyguladıkları politikaları aynen tekrar etmedikleri, öncekilerden çok daha sofistike ve ince ayarlı politikalar uyguladığı görülmektedir. 
Tablo 1: MINT ve Seçilmiş Bazı Ülkelerin Makro Ekonomik Gelişimi (2010-1990)

\begin{tabular}{|c|c|c|c|c|c|c|}
\hline & \multicolumn{3}{|c|}{ İnsani Gelişmişlik İndeksi*** } & \multicolumn{3}{|c|}{ Nüfus* } \\
\hline & 1990 & 2000 & 2010 & 1990 & 2000 & 2010 \\
\hline Meksika & 0.648 & 0.699 & 0.746 & 85.609 .404 & 102.808 .590 & 118.617 .542 \\
\hline Endonezya & 0.531 & 0.606 & 0.665 & 181.436.821 & 211.540 .428 & 241.613 .126 \\
\hline Nijerya & N/A & $\mathrm{N} / \mathrm{A}$ & 0.493 & 95.617 .345 & 122.876 .723 & 159.424 .742 \\
\hline Türkiye & 0.576 & 0.653 & 0.738 & 53.994 .605 & 63.240 .157 & 72.310 .416 \\
\hline Malezya & 0.641 & 0.723 & 0.769 & 18.211 .097 & 23.420 .751 & 28.119 .500 \\
\hline \multirow[t]{3}{*}{ Singapur } & 0.718 & 0.819 & 0.897 & 3.047 .100 & 4.027 .900 & 5.076 .700 \\
\hline & \multicolumn{3}{|c|}{ GSYiH Milyar (Dolar)* } & \multicolumn{3}{|c|}{ Kişi Başıına GSYiH (Dolar)* } \\
\hline & 1990 & 2000 & 2010 & 1990 & 2000 & 2010 \\
\hline Meksika & 262.709 & 683.647 & 1.049 .925 & 3.068 & 6.649 & 8.851 \\
\hline Endonezya & 114.426 & 165.021 & 755.094 & 630 & 780 & 3.125 \\
\hline Nijerya & 30.757 & 46.385 & 369.062 & 321 & 377 & 2.314 \\
\hline Türkiye & 150.676 & 266.567 & 731.168 & 2.790 & 4.219 & 10.135 \\
\hline Malezya & 44.024 & 93.789 & 255.016 & 2.417 & 4.004 & 9.069 \\
\hline \multirow[t]{3}{*}{ Singapur } & 36.152 & 95.833 & 236.421 & 11.864 & 23.792 & 46.569 \\
\hline & \multicolumn{3}{|c|}{ ihracat $($ Milyar Dolar)** } & \multicolumn{3}{|c|}{ İthalat (Milyar Dolar)** } \\
\hline & 1990 & 2000 & 2010 & 1990 & 2000 & 2010 \\
\hline Meksika & 40.711 & 166.367 & 298.305 & 43.548 & 179.464 & 310.205 \\
\hline Endonezya & 25.675 & 65.403 & 157.779 & 21.837 & 43.595 & 135.663 \\
\hline Nijerya & 13.596 & 20.975 & 84.000 & 5.627 & 8.721 & 44.235 \\
\hline Türkiye & 12.959 & 27.775 & 113.883 & 22.303 & 54.503 & 185.544 \\
\hline Malezya & 29.452 & 98.229 & 198.612 & 29.258 & 81.963 & 164.622 \\
\hline Singapur & 52.730 & 137.804 & 351.867 & 60.899 & 134.545 & 310.791 \\
\hline
\end{tabular}

Kaynak: *World Bank; ** World Trade Organisation; ***UNDP

Bu kapsamda geriden gelen ülke ekonomileri arasında potansiyel arz ettiği düşünülen ülkelerin aynı yolu izleyip izleyemeyeceği veya potansiyel olarak daha yüksek sıçrama ile yeni iyi örnekler oluşturup oluşturamayacakları bir gündem oluşturmakta ve ilgili literatür için yeni soruları beraberinde getirmektedir. Tablo 1, MINT ülkeleri ve seçilmiş bazı ülkelerin makroekonomik gelişimine ilişkin göstergeleri içermektedir ${ }^{9}$. Kişi başına düşen gelirin zaman içindeki gelişimi incelediğinde Meksika, Malezya, Singapur ve Türkiye'nin bu on yıllık periyotlarda gelirlerini istikrarlı biçimde arttırdıkları görülmektedir. Endonezya ve Nijerya'nın ise özellikle 2000'li yıllarda dikkat çekici biçimde gelir artışı yaşadıkları görülmektedir. Bu rakamlar Malezya, Meksika ve Türkiye'nin yüksek-orta gelir tuzağı; Endonezya ve Nijerya'nın da düşük-orta gelir tuzağı içinde olduğunu göstermektedir ${ }^{10}$. İnsani Gelişme Endeksi (IGE) açısından bir karşılaştırma yapıldığında ise Singapur'un $(0,897)$ en yüksek gelişmişlik düzeyine sahip olduğu görülmektedir. Bunu sırasıyla Malezya (0.769), Meksika (0.746) ve Türkiye (0.738) izlemektedir. Tablo 1'in yansıttığı göstergelerden, MINT ve seçilmiş ülke grupları açısından birkaç ülkenin öne çıkma potansiyeline ve gücüne sahip oldukları sonucu çıkmaktadır. Söz konusu olan bu potansiyelin iktisadi gelişmeye dönüşmesi izlenecek yerli üretim odaklı sanayileşme ve öğrenme temelli teknoloji transfer politikaları ile mümkün olabilecektir.

${ }^{9}$ MINT, BRICS gibi ülke gruplarını temsil eden yükselen ekonomilere ilişkin ilave bir kaç güncel okuma için bakınız: Yanık (2013);

Ünay ve Kayıkçı (2013); Atlı (2013); Özel (2013), Aytaç (2013)

${ }^{10}$ Ülkelerin gelir gruplarına göre sınıflandırılmasında, Dünya Bankası'nın Atlas metodu, görece en çok kabul edilen yöntem olarak ön plana çıkmaktadır. Bu yöntem kullanılarak yapılan hesaplamalara göre, kişi başına gayri safi yurtiçi hasılası 1.035 dolar ve altında olan ülkeler düşük gelirli ülkeler olarak sınıflandırılmaktadır. 1.036 dolar ile 4.085 dolar arasında gelire sahip ülkeler düşük-orta gelirli; 4.086 ile 12.615 dolar arasında gelire sahip ülkeler yüksek-orta gelirli ülkeler olarak sınıflandırılmaktadır. 12.616 dolar ve daha fazla gelire sahip ülkeler ise yüksek gelirli ülkeleri oluşturmaktadır. 


\section{TÜRKIYE EKONOMISINDE YERLI ÜRETIM TECRÜBELERI VE TEKNOLOJiK ÖĞRENME}

Dünya ekonomisinin son yıllardaki gelişimi izlendiğinde en dikkat çekici unsurlardan birisinin, gelişmiş ülkelerin de yakından ve dikkatle izlediği yükselen ekonomi gruplarının oluşumu ve gelişimi olduğu söylenebilir. Brezilya, Rusya, Hindistan ve Çin'den oluşan ve Büyük Dörtlü olarak da anılan BRIC grubu Güney Afrika'yı da kapsayan bir yapılanma ile dikkat çeken ilk yükselen ekonomi grubu olmaya başlamıştır. Türkiye'nin de içinde bulunduğu MINT, $\mathrm{N}-11$, ve MIKTA da son yıllarda ismi anılan yükselen ekonomiler grubu olarak yine gelişmiş ülkelerin yakından ve dikkatle izlediği ülkeler grubunu oluşturmaktadır. MINT ülkelerinin, gerek yüksek büyüme hızları ve olumlu ekonomik görünümleri, gerekse sahip oldukları nüfus, lokasyon ve emtia avantajlarıyla, gelecek on yıllar içeresinde hatırı sayılır bir kalkınma serüveni yaşayacakları tahmin edilmektedir (Karahan, 2014:7). Benzer öngörüler $\mathrm{N}-11$ ve MIKTA olarak anılan gruplar veya bu gruplardan ayrışmayı başarabilecek ülkeler için de yapılmaktadır. Bu tespitlerden yola çıkarakTürkiye'nin, yaklaşık on bin dolarlık bir gelir düzeyi ile orta gelir tuzağına yakalanmış olmasına karşın coğrafi konumu, genç nüfusu, yerli üretim konusunda gösterdiği çabalar göz önünde bulundurulduğunda yükselen ekonomiler arasında anılmaya başlamış olduğu söylenebilir. Ancak en önemli soru(n) "Türkiye'nin gelecekte nerede ve daha önemlisi nasıl bir konum alacağı" sorusudur. Ulusal teknolojik yeteneklerin ve üretim kapasitesinin, teknolojik öğrenme temelli kalkınmacı (yenilikçi, girişimci) devlet politikaları ile şekillendirilebilmesi kritik noktaya işaret etmektedir.

Çıkış yolunu, hedefleri net bir biçimde konulmuş ve yüksek, yerli teknolojiye odaklanmış bir sanayi politikası oluşturmaktadır. Türkiye'nin ithal girdilere olan yüksek derecedeki bağımlılığı (Akkemik, 2012), teknoloji özümseme ve öğrenme kapasitesinin potansiyelinin altında olması ve öğrenme temelli bir teknoloji transferi politikasının eksikliği (Tiryakioğlu, 2015b) ile uzun vadeli bir sanayi politikasının önemi daha belirgin hale getirmektedir. Bu kapsamda oluşturulacak, uygulanacak bir sanayi politikası Türkiye'nin karşı karşıya olduğu orta gelir tuzağından ve sanayisizleşme (de-industrialization) riskinden kurtulmasını sağlayacaktır.

Tarihsel gelişim süreci incelendiğinde 1920'li yıllarda uçak ile başlayan yerli üretim çabaları 1960 'lı yıllarda otomobil ve 1970 'li yıllarda motor ve bilgisayar üretimi ile zirveye ulaşmıştır. 1980 sonrası dönem ise hem devletin ekonomideki rolünün azaldığı hem de iktisadi ve siyasi iniş-çıkışlarla dolu istikrarsız bir dönem olarak sanayileşmenin ve dolayısıyla yerli üretim çabalarının gündemden düştüğü dönem olarak anılmaktadır. Şenses ve Taymaz' ın (2006:435) altını belirgin olarak çizdiği gibi, 1980 sonrasında diğer pek çok ekonomi politikasıyla birlikte teşvik politikalarında da önemli değişimler yaşanmış ve imalat sanayi teşviklerdeki önceliğini kaybetmiştir. Özellikle 2001 Krizi sonrasında yaşanan iktisadi toparlanmaya eşlik eden yükseliş sanayileşme çabaları genelinde, yerli üretim özelinde yeniden öğrenme dönemi olarak ifade edilebilir. Yülek (2010a, 2010b, 2010c) bütünsel bir bakış açısıyla, tüm bu süreçleri öğrenme-unutma-yeniden öğrenme dönemi olarak ifade etmektedir.

\subsection{Cumhuriyet Dönemi Sanayileşme Çabaları}

Türkiye, Cumhuriyet'in kuruluşu ile birlikte sanayileşme, öncelikli hedeflerden biri olarak alınmış ve devletin müdahaleci politikalarıyla şekillendirilmiştir. Kuruluş yılları olarak adlandırılan bu dönemin iktisadi olarak özellik ve önem arz eden ilk gelişmesi, henüz cumhuriyet ilan edilmeden, Şubat1923'te toplanan İzmir İktisat Kongresi olmuştur.

Cumhuriyet'in yeni ekonomi politikasının en önemli özelliklerinden birisi, Osmanlı Devleti'nin son döneminde gelişen 'milli iktisat' anlayışının ilk yansımasıdır. Kuruç (2011), milli iktisadın ilk yıllarda ekonomide, devlet ile özel kesimi birbirine bağlı tutan bir kavram olarak iktisat politikasındaki esas anlayışın 'milli' özel girişimciliğin desteklenmesi üzerine kurulu olduğunun altını çizmekte ve 1931 yılında İktisat Vekili olarak görev yapan Mustafa Şerif Bey'in 'milli iktisat' konusundaki fikirlerini şu şekilde aktarmaktadır:

"Bu memlekette bir vakitler şimendiferler, bankalar, ticaret, sanayi, millî şirketlerin hisse senetleri, hatta en iyi tarlalar ve şehirler dahilindeki en iyi emlâk Türklerin değil ecnebilerin elinde idi. Bu memleket, tarihinde, milli iktisat namına hiçbir mefhum (kavram) kavrayamamıştır. Milli iktisattan bahsetmek, bir vakitler bir kabahat, bir vakitler de muammadan (bilmeceden) bahsetmek gibi bir şeydi." (s.299)

Teşvik-i Sanayi Kanunu ile yerli üreticiyi koruyan, destekleyen ve üretim konusunda teşvik eden bir yapı oluşturulmaya çalışılmıştır. Ayrıca Sümerbank 
ve Etibank'ın kurulması milli sanayi ve milli iktisadın tesisi için önemli adımlar oluşturmaktadır. Kalkınmanın finansmanını da amaçlayan bu kurumlar bünyelerinde kurulan pek çok şirket ile ekonomik altyapının güçlenmesini ve aynı zamanda nitelikli teknik personelin yetişmesini sağlamıştır. 1930'lu yıllarda Devletçilik anlayışı altında şekillenen milli iktisat oluşturma düşünce ve gayretleri, liberal iktisadi düşüncenin öngördüğü özgürlüğü sınırlamakta ve yerli sermayenin desteklenerek ulusal düzeyde sermaye birikiminin sağlanabilmesi için bir çerçeve çizmektedir. Büyük ölçüde, bütçeden ayrılan kaynaklarla yürütülen devletçi sanayileşme programının uygulanması esnasında iç ve dış borç yükü arttırılmadığı ve açık finansman yoluna gidilmediği gibi sanayi birimlerinin kurulmasında genellikle o dönemin en ileri teknolojisi kullanılmıştır (Kepenek ve Yentürk, 2001:69). Bu dönem Türkiye'nin teknolojik öğrenme sürecinin etkin olarak gerçekleştirdiği ve ulusal teknolojik yetenek ve kapasitesini geliştirdiği bir döneme işaret etmektedir. $\mathrm{Bu}$ gelişmenin somut çıktıları ise Türk havacılık sanayinde kendini göstermektedir (Okar, 2010; Orbay, 2009; Yalçın, 2013).

Yerli sermayenin oluşturulmaya ve korunmaya çalışıldığı bu döneme damgasını veren en önemli gelişmelerden birisi, pilot astsubay Vecihi Hürkuş tarafından, 1924 yılında Yunanlılardan ganimet olarak ele geçirilen motorlardan yararlanılarak ilk Türk uçağının imal edilmesidir. Türk havacılık tarihinin en önemli isimlerinden birisi olarak bilinen Vecihi Hürkuş, öncelikle 1. Dünya Savaşı'na ve Kurtuluş Savaşı'na katılarak başarılı keşif ve destek uçuşları gerçekleştirilmesi ile anılmaktadır. Savaş sonrası dönemde, bugün Gaziemir Hava Teknik Okullar Komutanlığı olarak anılan İzmir Seydiköy Hava Mektebi'nde uçak yapımı projesi ile ilgilenmiş ve 28 Ocak 1925'de"Vecihi K-VI"adını verdiği uçağı uçurmayı başarmıştır. Hürkuş, bu sebeple cezalandırılmasının ardından askeri havacılıktan ayrılarak uçak tasarımı ve yapımı çalışmalarına devam etmiştir (Wikipedia, Vecihi Hürkuş maddesi).

1932'de ilk Türk sivil havacılık okulu olan Vecihi Sivil Tayyare Mektebi'ni ve 1954'te ilk sivil havayolu şirketi Hürkuş Havayolları'nı kuran Vecihi Hürkuş ile birlikte Türk havacılık tarihinin en önemli isimlerinden biri olarak bilinen ve Türkiye Cumhuriyeti'nin yapılandırılması sürecine demiryolu yapımıyla katkı sağlayarak Atatürk tarafından Demirağ soyadı verilen Mühürzade Mehmet Nuri Bey'dir. Nuri Demirağ,
1933 yılında Vecihi Hürkuş tarafından kurulan Sivil Havacılık Okulunu ziyarete geldiğinde kendisine destek olmuş ve bu alandaki çalışmalara ivme kazandırmış bir kişi olarak Türk havacılık tarihinde önemli bir yere sahiptir. Nuri Demirağ aynı zamanda müteşebbis yönüyle pek çok alanda başarıya imza atmıştır. Avrupa ve Amerika'daki son model uçaklara karşın yeni bir Türk tipi uçak geliştirmek düşüncesiyle ve Selâhattin Alan'ın teknik bilgi birikimiyle çalışmalara başlamıştır. Türk havacılık tarihinin önemli isimlerinden bir diğeri, Fransa'da eğitim görmüş ve ülkesine dönerek ikinci milli uçak projesine imza atmış uçak mühendisi Selâhattin Alan'dır. 1932 yılında "MMV-I" isimli iki kişilik uçağı tasarlamış ve uygulamıştır. Hemen ardından Nuri Demirağ tarafından desteklenen ve onunla birlikte "NuD.36" ve "NuD.38" uçaklarının tasarım ve imalâtını gerçekleştirmiştir ki bu uçak Türk Hava Kurumu'nun siparişi üzerine 24 adet üretilmiştir. Kontrol uçuşu sırasında yaşanan talihsiz bir kaza sonucunda Selâhattin Alan'ın hayatını kaybetmesi, uçak sanayindeki gelişmelerin aksamasına sebep olmuştur (Dervişoğlu, 2010:54-56).

1925 yılında Alman ortaklığı ile kurulan Kayseri Tayyare ve Motor Türk Anonim Şirketi (TOMTAŞ) ile faaliyete geçen Kayseri Uçak Fabrikası, alınan lisanslarla çeşitli tip ve niteliklerde uçak imalâtında bulunmuştur. Hem kamuya hem de özel sektöre hizmet eden, bakım ve onarım hizmetleri sunarak çeşitli teçhizat üretimi gerçekleştiren fabrikada 1950 yılında uçak imalâtı durdurulmuş ve "Kayseri Hava İkmal ve Bakım Merkezi"ne dönüştürülmüştür. Bununla birlikte 1944 yılında Ankara, Etimesgut'ta kurulan Türk Hava Kurumu, Uçak Fabrikası da 1952 yılında maddi sorunlar gerekçe gösterilerek Makine Kimya Endüstrisi Kurumu'na devredilmiştir. Faaliyet gösterdiği sürece yerli ve yabancı tedarikçilerin desteği ile çeşitli nitelikte uçaklar üretilmiştir.

Cumhuriyet döneminin en önemli girişimlerinden biri olarak nitelendirilebilecek bir diğer yapılanma TUSAŞ Havacılık ve Uzay Sanayii Anonim Şirketi'dir. 15 Mayıs 1984 tarihinde F-16 Uçaklarının üretimi amacıyla Akıncı-Ankara'da Türk ve $A B D$ 'li ortaklar tarafından kurulan TUSAŞ Havacılık ve Uzay Sanayii Anonim Şirketine ait yabancı hisseler 2005 yılında Türk hissedarlar tarafından satın alınarak şirket yeniden yapılandırılmış ve TUSAŞ-Türk Havacılık ve Uzay Sanayii A.Ş. (TUSAŞ) adı altında faaliyetlerini geliştirerek, havacılık ve uzay sanayi sistemlerinin geliştirilmesi, modernizasyonu, üretimi, sistem 
entegrasyonu ve yaşam döngüsü destek süreçlerinde Türkiye'nin teknoloji merkezi konumuna gelmiştir (Tusaş Web Sitesi). Son dönemde ilk Türk insansız hava aracının ve eğitim başlangıç uçağının üretimiyle gündemde yer alan TUSAŞ Türk havacilık sanayinin stratejik kurumlarından biri olarak faaliyetlerini sürdürmektedir.

\subsection{Planlı Kalkınma Dönemi ve Yerli Üretim}

Yaklaşık yirmi yıllık bir dönemi (1960-1980) kapsayan planlı kalkınma döneminin en önemli özelliklerinden birisi, dönemin ithalât yerine "yerli üretim" (ithâl ikâmesi) yoluyla sanayileşmenin bilinçli bir uygulamasının yaşanmasıdır (Kepenek ve Yentürk, 2001:141). 27 Mayıs 1960 Askeri darbesinin ardından başlayan planlı kalkınma dönemi Türkiye ekonomisi için özellik arz etmektedir. Planlamanın merkezî kuruluşu olarak kabul edilen Devlet Planlama Teşkilâtı (DPT) bu dönemde kurulmuştur. Planlı dönemin ilk kurumu olan DPT'nin hazırladığı Birinci Beş Yıllık Kalkınma Planı (1963-1967) kapsamında, ülkenin bilim ve teknoloji politikalarının tesisi için hayati önem taşıyan Türkiye Bilimsel ve Teknik Araştırma Kurumu'nun (TÜBITAK) kuruluşu da yer alıyordu. 1963 yılında, temel ve uygulamalı araştırmaların geliştirilmesi, teşviki, düzenlenmesi ve koordinasyonu amacıyla kurulan TÜBITAK, günümüzde Bilim, Sanayi ve Teknoloji Bakanlığı'na bağlı olarak faaliyet göstermekte ve yerli üretimin desteklenmesi konusunda her geçen yıl çeşitlenerek artan destek mekanizmalarını koordine etmektedir.

Kritik bir adım olarak TÜBiTAK'ın kurulduğu bu yıllar Türkiye'de yerli üretim konusunda çok önemli adımların atıldığı yıllara denk gelmektedir. Necmettin Erbakan'ın fikri önderliği ve 1960 Askeri Darbesi sonucunda iktidarda bulunan askeri hükümetin başında bulunan Cemal Gürsel'in talimatlarılya üretilen (iki adet) Devrim otomobili, Türkiye'nin sanayileşme tecrübelerindeki en önemli kırılma noktalarından birini oluşturmaktadır. "Yerli Sanayii demek Iktisadi Özgürlük demektir" inancıyla küçük bir teknik ekibin, çok kısa bir sürede (yaklaşık 4 ay) hayata geçirdikleri bu proje, dönemin teknolojik imkânları ve benzer konumdaki ülkelerin üretim yetenekleri ile kıyaslandığında çok önemli bir başarı olarak ifade edilmektedir. Sürdürülebilirliği sağlanamayan bu proje, sağladığı pozitif dışsalık ile demiryolları alanında önemli bir üretim kapasitesinin oluşumunu sağlamıştır. Şimşek'e (2008: xi) göre, demiryolları bu projeden sonra yolcu vagonu ve dizel lokomotif yapma cesaretini bulmuş, 1962 yılında yolcu vagonu, 1965 yılında manevra lokomotifi yapılmıştır. Yine aynı dönemde, 1956-1963 döneminde Erbakan'ın öncülüğünde kurulan 200 ortaklı Gümüş Motor şirketi, tamamen yerli motor üretimini yapmıştır.

1970'li yılların sonunda, Zaylok firmasının ürettiği Z80 mikro işlemcisini kullanan bir grup araştırmacı Uslu adını verdikleri ilk yerli bilgisayarı üretmiştir. Yine aynı dönemde Boncuk 09 adı verilen bir başka yerli bilgisayar da üretilmiş ve hatta aralarında rekabet eder duruma gelmişlerdir (NTVMSNBC, 2000). Boncuk 09 'u üreten Mega Elektronik firması tarafından 197980 yıllarında üretilen Boncuk 09, ilgili firmanın devamı niteliğinde faaliyetlerine devam eden Elisa Elektronik firmasının internet sitesinde aktarıldığı üzere, toplama bir bilgisayar değildir ${ }^{11}$. Ana kartı, grafik kartı ve bellek kartı gibi tüm kartları Mega Elektronik kurucuları tarafından tasarlanıp, yazııımı dâhil üretimi de Türkiye'de gerçekleştirilmiştir. Boncuk 09 bilgisayar olarak birçok müşterinin kullanımına verildiği gibi bilgisayar altyapısı da birçok projede özel tasarımlar için kullanılmıştır. Benzer bir tecrübe, bu kez cep telefonu üretiminde, 1990'lı yıllarda yaşanmıştır. Aselsan tarafından üretilen ilk yerli cep telefonu Aselsan-1919 (Aselsan-1920 ise 1999 yılında piyasaya sürülmüştü), benzer şekilde kısa sürede geliştirilerek 1997 yılında ilk örneğini piyasaya sunmayı başarmıştır. iç pazarın yanı sıra Azerbaycan ve Kuzey Kıbrıs Türk Cumhuriyeti gibi yakın coğrafyada ilgi ile karşılanmış ve beş bin adetten fazla üretilmiş ve satılmıştır (Özkan, 1997). Dünyada, henüz günümüzün küresel ölçekli bilgisayar firmalarının pek çoğu kurulmamışken, iki farklı bilgisayar ve cep telefonu üretebilen Türkiyesnin yerli üretim konusundaki en büyük zafiyeti, ne yazık ki Devrim'de olduğu gibi bilgisayarların da, cep telefonlarının da seri üretimlerinin sağlanamamış olmasıdır.

\subsection{Dışa Açılma Dönemi ve Kriz Yılları}

1980'li yıllar, Türkiye ekonomisinde dışa açılma dönemi olarak adlandırılabilecek özel bir dönemi ifade etmektedir. Kazgan (2006:121), 24 Ocak Kararları ile gelmesi amaçlanan serbestleşmenin, dış kaynaklı küresel bir projenin Türkiye ayağı olduğunu vurgulamakta ve $A B D$ 'de Reaganomics ve Ingiltere'de Thatcherism ile yola çıkan serbestleşme politikasının, Türkiye'ye yansıması olarak ifade etmektedir. Chang (2009), 'Kalkınma Reçetelerinin Gerçek Yüzü' adıyla Türkçeleştirilen ünlü eserinde, gelişmiş ülkelerin, gelişmekte olan ülkelerin

${ }^{11}$ http://www.elisa.com.tr/coezuemler/oezel-elektronik-sistemler 186 
yetişmelerini engellemek amacıyla serbestleşme hareketini önerdiklerini ve desteklediklerini vurgulamaktadır. Johnson'un (1982) tarafından Japonya'nın ekonomik kalkınma tecrübelerini yansıtan bir çalışmada kavramsallaştırılan "Kalkınmacı Devlet"in, özellikle gelişmekte olan ülkelerin geç kalkınma ve sanayileşme başarıları için oynayacağı etkin rol bu yaklaşımlarla gözardı ediliyordu ${ }^{12}$. Pek çok gelişmiş ülke ile birlikte Türkiye'yi de etkisi altına alan bu serbestleşme dönemi, sanayileşme stratejisi açıdan bakıldığında 1980 sonrası dönemin önceki dönemden, birbirleriyle yakından ilişkili üç özellik itibariyle birbirinden ayrılmaktadır (Şenses ve Taymaz, 2006:431-433):

1. Bunlardan birincisi, 1980 öncesi döneme damgasını vuran korumacı ve ithal ikamesine dayalı içe dönük sanayileşme politikalarının yerini ekonominin dünya ekonomisiyle daha yakından ilişkilendirilmesini ve bütünleşmesini amaçlayan dışa dönük politikalara bırakmasıdır. Dış ticarette miktar kısıtlamaları kaldırılarak ve gümrük vergileri çok büyük ölçüde düşürülerek dış ticaret liberasyonu yolunda 1980'li yıllarda önemli bir mesafe katedildikten sonra Ağustos 1989 'da sermaye hareketlerinin serbest bırakılması ve 1980 yılı başlarından başlayarak doğrudan yabancı sermaye akımları üzerindeki kısıtların kaldırılması bu amaca yönelik en önemli adımları oluşturmuştur.

2. 1980 sonrası dönemi önceki dönemden ayıran ikinci özellik, devletin ekonomi alanındaki rolünde gözlenen belirgin değişikliklerdir. 1980 öncesinde devlet, çeşitli dış ticaret ve kambiyo kontrolleri yanında, döviz kuru ve faiz oranlarının belirlenmesi, özellikle kamu bankaları aracılığıyla kredilerin belirli imalat sanayii dallarına ve küçük üreticilere yönlendirilmesi, kredi ve dış ticaret teşvikleri ve Kamu İktisadi Teşebbüsleri'nin ürettiği mal ve hizmetlerin düşük fiyattan sunulması yoluyla özel sektöre sağlanan avantajlar, bölgesel teşvikler ve yabancı sermaye üzerindeki denetimi aracılığıyla sanayi politikasında belirleyici bir unsur olarak ön plana çıkmıştır. 1980 sonrasında ise, bu gelişmelerin tam aksine, devletin sanayileşme sürecini etkileyen belli başlı bütün araçlarının elden çıktığı ve devletin rolünün hızla azaltıldığı bir döneme girilmiştir.
3. 1980 sonrası döneminin üçüncü temel özelliği, sanayileşmeye ilişkin temel yaklaşımların ve politikaların oluşturulmasında dış dinamiklerin ön plana çıkmasıdır. Özellikle tam üyelik başvurusunun yapılmasından sonra Avrupa Birliği ile ekonomik ilişkiler belirgin bir şekilde yoğunlaşmış olsa da 1980 sonrası dönemde bu konudaki belirleyici dış etkiler ağırlıkla Bretton Woods Kuruluşları'ndan kaynaklanmıştır.

Özellikle finans sektörünün liberalleştirilmesini hedefleyen düzenlemelerin en önemli başarılardan birisi ihracat artışı olmuştur. 1980'li yılların ilk yarısında özelikle Irak-İran Savaşı sebebiyle genişleyen pazar imkânları sonucunda Türkiye'nin Ortadoğu ihracatı, Avrupa'ya yapılan ihracatı geride bırakmıştır (Pamuk, 2014:269). Yine Pamuk (2014:270) tarafından altı özellikle çizilen döneme ilişkin durum, faizlerin yüksekliği, siyasal ve kurumsal istikrarın yerleşememesi ve yeni politikaların kalıcı ve istikrarlı olacağı doğrultusunda güvencenin verilememesi gibi sebeplerle imalât sanayi yatırımlarının düşük kalmasıdır. İhracata yönelen sanayilerde bile, iç talebin sınırlı kalmasının da etkisiyle yeni kapasite oluşumundan ziyade mevcut kapasitenin korunması ve yönetilmesi yönünde bir eğilim oluşmuştur.

1990'lı yıllara gelindiğinde ise hem Türkiye'nin yaşadığı ekonomik krizler, hem dünyada yaşanan bölgesel ve küresel ölçekli krizler ve Türkiye'ye yansımaları hem de ülkenin 1999 yılında yaşadığı iki büyük deprem sanayileşme faaliyetlerini olumsuz etkilemiştir. Türkiye ekonomisi (ve pek çok gelişmekte olan ülke ekonomisi, hatta dünya ekonomisi için) için kayıp yıllar olarak anılan 1990'lı yıllar ekonomik ve siyasi istikrarın sağlanmasına odaklanılmış bir dönemi ifade etmektedir.

\subsection{Türkiye'de Sanayi(leşme) Politikası}

Sanayileşmenin büyük ölçüde gündemden düştüğü 1980 sonrası dönemde, devletin sanayileşmedeki rolü, sektöre yönelik oluşturulan politikalar, yatırım teşvikleri, özellikle 1990'ı ııllardan itibaren küçük ve orta boy işletmelere (KOBI) yönelik politikalar ve firmaların teknolojik gelişmeye dönük faaliyetlerinin teşvikini amaçlayan bilim ve teknoloji politikalarıyla sınırlı kalmıştır (Şenses ve Taymaz, 2006:434). Bu durumun temel etkileri Türkiye'nin sanayileşme vizyonu anlamında, aynı dönemde veya daha önce sanayileşme girişimleri gösterdiği

${ }^{12}$ Kalkınmacı devlet, kalkınma iktisadı yazınında, özellikle yakalama başarısı açısından önemli bir faktör olarak yer almaktayken, son yıllarda kalkınmacı devlet, günümüzde yeni-kalkınmacı devlet biçimiyle 'girişimci devlet' (Mazzucato, 2013), inovatif (yenilikçi) devlet (Chopra, 2014) gibi kavramlarla anılmaktadır. 
Güney Kore gibi ülkelere göre, geri kalmasına sebep olmuştur. Taymaz ve Voyvoda (2012) 1980 sonrası dönemde, Türkiye'nin başarılı bir takipçi ülke olmasına rağmen, Güney Kore ile karşılaştırıldığında sanayide yapısal dönüşümü gerçekleştiremediğinin altını çizmekte ve aradaki farkın temel nedeninin de Güney Kore'de devletin uyguladığı proaktif ve uzun soluklu sanayi politikaları olduğunu belirtmektedirler. Öniş ve Şenses (2009:708-709) Türkiye (ve benzer özellikler taşıyan Latin Amerika ülkeleri) ile Güney Kore'nin başı çektiği Doğu Asya bölgesi arasındaki "geç-sanayileşme" açığını, reaktif ve proaktif devlet kavramları ile açıklamaktadır ${ }^{13}$. Bu çalışmanın devamı niteliğindeki bir başka çalışmada, Öniş ve Kutlay (2013), Türkiye'de son zamanlarda proaktif bir sanayi stratejisi denenmekte olduğunu ve bu durumun regülatör (düzenleyici) devlete dönüşümün sürdüğü 2001 sonrası dönemle benzeştiğini vurgulamaktadır. Regülatör devletin rolü, piyasa başarısızlıklarının kaynak dağılımını bozucu etkilerini ortadan kaldırmaya yönelik düzenleyici kamu müdahalesi olarak tanımlanabilir. Bu müdahale, bağımsız düzenleyici kurumlar (ya da otoriteler) aracılığıyla gerçekleştirilmektedir ${ }^{14}$. Aynı çalışma kapsamında Öniş ve Kutlay (2013), Türkiye'nin son dönemlerdeki politik ekonomisine ilişkin yaptıkları analizde, 2001 krizi sonrasında ve 2008 küresel krizi sonrasında Türkiye'de regülatör (düzenleyici) kurumların güçlendirildiğini ancak Doğu Asya'da olduğu gibi beraberinde bir sanayileşme vizyonu getirmediğini belirtmektedirler. Düzenleyici ve denetleyici kurumların sanayileşmeyi ve yerli üretimi odak noktasına alan bir politika önceliğine sahip olmaması, bu eksikliğin temel sebebi olarak ifade edilebilir. Ayrıca, devlet düzenlemelerinin birbiriyle çelişmesine yönelik güçlü intimaller, uygulama zorlukları ve düzenleyici kurumların tamamen bağımsız olamamaları da bu kapsamda göz önünde bulundurulması gereken unsurlardır. Türkiye'nin kurumsal yapıdaki düzenlemeye ilişkin çok yönlü girişimlerine karşılık devletin sanayileşme ve yerli üretim konusunda yeterince belirleyici bir role sahip olmadığı görülmektedir.

Türkiye'nin Avrasya bölgesinde orta ve yüksekteknolojili ürünlerde üretim üssü haline getirilmesi hedefi ile hazırlanan Türkiye Sanayi Strateji Belgesi (2011-2014), bir sanayi politikası çerçevesi çizmek amacıyla hazırlanmış ve bu kapsamda ihracattayüksek teknolojili ürünlerin payının artırılması ve yüksek katma değerli alanlara geçişin sağlanması gibi önemli hedeflere yer verilmiştir. Raporda önemli hedeflerin konulmuş ve sanayileşme konusunda bir vizyonun çizilmiş ve (i) Orta ve yüksek teknolojili sektörlerin üretim ve ihracat içindeki payının arttırıması, (ii) Düşük teknolojili sektörlerde katma değeri yüksek ürünlere geçişin sağlanması ve (iii) Becerilerini sürekli geliştirebilen şirketlerin ekonomideki ağırlığının arttırılması olmak üzere üç temel stratejik hedef tespit edilmiştir. Bu belge Türkiye'ye ilişkin hedefleri net bir biçimde belirlenmiş bir sanayi politikası önermek konusunda bir ilk adım niteliği taşımaktadır ${ }^{15}$. 20152018 yıllarını kapsayan Türkiye Sanayi Strateji Belgesi ise çok daha spesifik bir tema ile hazırlanmış ve çok daha net hedeflerle yayımlanmıştır. Bu belge kapsamında yer verilen stratejik hedefler ise, (i) Sanayide bilgi ve teknolojiye dayalı yüksek katma değerli yerli üretimin geliştirilmesi, (ii) Kaynakların etkin kullanıldığı, daha yeşil ve rekabetçi sanayi yapısına dönüşümün sağlanması ve (iii) Sosyal ve bölgesel gelişmeye katkı sağlayan ve nitelikli işgücüne sahip sanayinin geliştirilmesi şeklinde sıralanmaktadır. Yerli, yenilikçi ve yeşil üretim vurgusu ile yayımlanan bu ikinci raporun birinci rapora göre, çok daha belirgin hedeflerle oluşturulduğu görülmektedir.

Takip eden başlıkta ayrıntılı olarak ele alınacağı gibi yerli üretimi gerçekleştirilen ve özellikle savunma sanayii için stratejik öneme sahip olan yerli helikopter, savaş gemisi, tank, tüfek ve insansız hava aracı gibi orta ve yüksek teknolojili ürünler bu yöndeki dönüşümün elde ettiği başarıya dikkat çekmektedir. Bu aşamada üzerinde durulması gereken en önemli hususlardan

\footnotetext{
${ }^{13}$ Öniş ve Şenses (2009) reaktif ve pro-aktif devlet kavramlarını, kalkınmacı devletin farklı birer biçimi olarak ele almaktadır. Doğu Asya Modelindeki devlet biçimi pro-aktif (önde giden), Latin Amerika ve Türkiye'de ise reaktif (takip eden) devlet biçimleri kendini göstermektedir. Pro-aktif devletler, önemli politika değişikliklerini büyük krizler yaşamadan önce kendi inisiyatifleriyle gerçekleştirebilen devletler olarak; Reaktif devletler ise, krizler ortaya çıktıktan sonra bir tepki olarak harekete geçen devletler olarak tanımlanmaktadır. Kalkınmacı devlet ve biçimleri hakkında ayrıntılı bir diğer çalışma için bakınız Oğuz, 2013

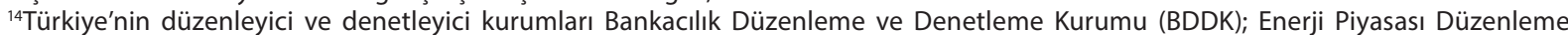
Kurumu (EPDK); Kamu İhale Kurumu (KiK); Radyo ve Televizyon Üst Kurulu (RTÜK); Rekabet Kurumu; Sermaye Piyasası Kurulu (SPK); Bilgi Teknolojileri ve İletişim Kurumu, Kamu Gözetimi Muhasebe ve Denetim Standartları Kurumu; Özelleştirme İdaresi Başkanlığı; Şeker Kurumu ve Tütün, Tütün Mamulleri ve Alkollü Içkiler Piyasası Düzenleme Kurumu olarak sayılabilir.

${ }^{15} \mathrm{Bu}$ konudaki eleştirel birkaç değerlendirme için bakınız: Kayıkçı (2011); Küçükkiremitçi (2011); Şahinkaya (2011). Bilim, Sanayi ve Teknoloji Bakanlığı da düzenli olarak Türkiye Sanayi Stratejisi Belgesi'ne (2011-2014) ilişkin Uygulama, İzleme ve Değerlendirme Raporları yayımlamaktadır. Bu Raporlara: http://sanayipolitikalari.sanayi.gov.tr/Public/StrategieReports adresinden erişilebilmektedir. 
birisi yenilikçi ve rekabet gücü yüksek yerli üretimin gerçekleştirilmesi, sürdürülmesi ve pazarlanabilmesi için izlenmesi gereken ekonomi politikalarının nasıl olması gerektiğidir. Bu yaklaşımı odak noktasına alan strateji belgeleri ve kalkınma planları incelendiğinde ise hedefleri ve sektörel öncelikleri net bir biçimde belirlenmiş bir sanayi politikasının eksikliği belirgin olarak gözlemlenmektedir.

\subsection{Yerli Üretimin (Yeniden) Artan Önemi}

Türkiye'de 1980 sonrası dönem, gerek Türkiye gerekse dünya ekonomisi için kayıp yıllar olarak anılmaktadır. Bu yönüyle 1990'lı yıllar hem ekonomik hem de siyasi istikrarın sağlanması amacına odaklanılmış bir dönemi ifade etmektedir. Bu dönemde yerli üretime ilişkin belirgin gelişmeler sağlanamamış, özellikle 1930 'lu yıllardan başlayarak elde edilen birikim ve yerli üretim kapasitesinin unutulmaya başladığı bir dönem yaşanmıştır. 2001 Krizinin ardından yaşanan toparlanma dönemimde ise tek parti hükümeti ve yerli üretim ekonomisi konusundaki çabalar, geçmiş yıllarda oluşan birikimin yeniden değerlendirilmesini kolaylaştırmış, yerli üretim yeteneklerinin hatırlanarak kapasitenin daha hızlı bir biçimde gelişimi sağlanmıştır.

Bütünsel olarak incelendiğinde, özellikle 2000'li yılların ikinci yarısından itibaren Türkiye'nin yerli üretim çabaları ve vizyonu özellikle savunma sanayii alanında somut çıktılarını vermeye başlamıştır. Yerli savaş gemisi Milgem, yerli insansız hava aracı Anka, yerli tank Altay, yerli helikopter Atak, yerli eğitim uçağı Hürkuş, yerli gözlem uyduları Bilsat (2001), Rasat (2011) ve Göktürk-2 (2012) üretilerek test kullanımları yapılmıştır. Savunma sanayine yönelik havacılık endüstrisi odaklı bu yerli üretim tecrübeleri konusunda tamamlayıcı yazılımların da yerli üretiminin sağlanıyor olması önemli gelişmeler kaydedildiğinin bir göstergesidir. Rasat'da yerli olarak tasarlanan ve üretilen Bilge isimli uydu görev bilgisayarı, T-Reks isimli X-Bant haberleşme sistemi ile Gezgin isimli gerçek zamanlı görüntü işleme modülleri kullanılmaktadır (TUSAŞ web sitesi).

27 Eylül 2011 tarihinde hizmete alınan TCG Heybeliada (F-511) ve 27 Eylül 2013'te hizmete alınan ikinci gemi Büyükada (F-512)'de yerli olarak geliştirilen savaş sisteminin (Genesis) entegrasyonu ile birlikte tasarım, entegrasyon ve analiz aşamaları tamamen yerli olarak gerçekleştirilmektedir. Tasarımı Türk mühendislerince gerçekleştirilen ve üretiminde yerli alt yüklenici firmalarıN da görev aldığı Türk
Insansız Hava Aracı Anka'nın montajı ve üretimi 16 Temmuz 2010 tarihinde tamamlanmış ve hangardan çıkmışır. Hangardan çıktıktan sonra motoru da çalıştııılan Anka'nın, kendi kategorisinde dünyanın en iyi operatif sistemi olması hedeflenmektedir (TUSAŞ web sitesi). 2008 yılında projelendirilmeye başlayan ilk yerli tank Altay'ın ilk iki prototipi 2012 yılında test sürüşleri ve kullanımı başarı ile tamamlanarak yerli üretim yetenekleri arasında yerini almıştır. Illk yerli eğitim uçağı Hürkuş, 29 Ağustos 2013'te hangardan çıkarak ilk test uçuşunu başarı ile gerçekleştirmiştir. Ve nihayet 10 Haziran 2014 tarihinde Türkiye'nin ilk taarruz ve taktik keşif helikopteri T-129 Atak da ilk uçuşlarını başarı ile tamamlayarak havacılık ile ilgili savunma sanayi fuarlarında yerini almaya başlamıştır. Bu önemli ve sağlam adımlar Türkiye'nin yerli üretim konusunda 'yerli otomobil'den çok daha yüksek kabiliyet ve kapasiteye sahip olduğunu göstermektedir.

Türkiye'nin yerli üretim çabalarının etkinliğini sağlayacak en önemli sanayi politikası araçlardan birisi kamu satın alımlarıdır. Yerli üretim kapasite ve yeteneklerinin arttırılabilmesi için önemli bir araç olan kamu alımları, Tiryakioğlu ve Yülek (2015) tarafından gelişmekte olan ülkelere yönelik bir araç olarak ele alınmakta ve kalkınma temelli kamu alımları olarak tanımlanmaktadır. Kalkınma temelli kamu alımları, gelişmiş ülkelerin yeniliği teşvik eden ve geliştiren yaklaşımlarına karşın gelişmekte olan ekonomilerde bir kapasite oluşturma ve arttırma aracı olarak ele alınmaktadır. Gelişmekte olan ekonomilerde teknoloji ve yenilikçilik politikalarının başarılı olması için gelişmiş kabiliyetlere sahip sanayi şirketlerinin yetiştirilmesi gerekmektedir. Bu tür bir altyapı ve kapasite oluşturulmaksızın, gelişmiş ekonomilerde kullanılan yenilikçilik ve teknoloji desteklerinin kullanılması, bu politikaların etkinliğini azaltmaktadır. Bu kapsamda, kamu satın alma politikalarının gelişmekte olan ülkelerde kullanımını ele alan Yülek ve Taylor (2012) ve Yülek (2012), gelişmekte olan ülkelerde makine ve donanım ithalatının ihmal edilemez boyutlara yükseldiğini ve bunun, doğru satın alma politikalarının tasarlanmasıyla, yerli şirketlerin sınâ̂ yeteneklerini yükseltmekte kullanılabileceğini önermektedir. Benzer şekilde, Watermeyer (2012), kamu satın alma politikalarının 'ikincil' ya da 'sosyal' amaçlarının ülkedeki iktisadi kalkınmayı hızlandırma amaçlarına nasıl yönlendirilebileceğini tartışmaktadır.

Türkiye açısından, Fırsatları Arttırma ve Teknolojiyi Iyileştirme Hareketi olarak açıklanan Fatih Projesi 
önemli bir kamu alımı projesi olarak çeşitli fırsatlar sunmaktadır. Uygulanabilirliği, bilişim ve yazılım altyapısı konusunda her ne kadar tartışmalı bir proje olsa da yerli üretim kapasite ve yeteneklerinin arttırılması açısından önemli fırsatları beraberinde getirmektedir. 6 Eylül 2011 tarihli 28046 sayılı Resmi Gazete'de yayımlanan Yerli Ürün Kullanımına İlişkin Genelge, Resmi Gazetedeki ifadeyle, "tasarruf ve rekabet ilkelerine uygun hareket edilmesi kaydıyla, ülkemiz ihtiyaçlarının yerli ürünlerden karşılanması, ekonomimiz açısından büyük önem taşımaktadır.

\section{SON SÖZ: GELECEĞE İLIŞKIN SORU(N)LAR}

Çalışma kapsamında ayrıntılı olarak ele alınan gelişmeler, Türkiye'nin, iyi örnekler olarak anılan ve sanayileşme tecrübeleri aktarılan ülkelere benzer bir yolu, daha kısa sürede ve daha yenilikçi yöntemlerle geçebileceğine ve uluslararası rekabet gücünü artırabileceğine işaret etmektedir. Türkiye ekonomisinin dünya ekonomisi içerisinde uzmanlaştığı ürünlerdeki dönüşümler de bu yöndeki gelişim potansiyeline ilişkin bir gösterge olarak yorumlanabilir. Bununla birlikte Taymaz vd. (2011) tarafından yapılan bir çalışmada, Türkiye'nin yöneldiği pazarların diğer pazarlardan daha hızlı büyümesinin, ihracatı hızlı şekilde arttırdığından bahsedilmekte ve Türkiye'nin pazar avantajlarını ve coğrafi konumunu iyi kullanabildiğinin altı çizilmektedir. Ancak bu olumlu gelişmelere ve görünüme karşın ülkeler ile aradaki refah farklılığının azalmadığı görülmektedir. Hızlı büyüyen, teknolojik olarak gelişmiş ürünlerde rekabetçiliği yakalayamayan Türkiye, uluslararası ekonomideki konumunu güçlendirememiştir. Taymaz vd. (2011), Türkiye'nin son on yılda uluslararası ekonomi içerisindeki uzmanlaştığı ürünlerin ve sektörlerin, genel olarak büyüme hızları düşük olan ürünler ve sektörler olduğunu ve göreli fiyatların düşük olduğu ürünlerde daha rekabetçi olabildiği yönünde bir bulgulara erişmişlerdir.

Türkiye'nin uzun dönemde ekonomik gelişmesini sürdürebilmesi, rekabet gücünü arttırabilmesi ve uluslararası piyasalarda konumunu güçlendirebilmesi için teknolojik yetenek birikiminin arttırılmasına, yenilikçilik temelli iktisadi faaliyetler ile üretkenlik artışı sağlanmasına, üretim ve ihracat yapısının teknoloji yoğun ürünlere dönüştürülmesine odaklanmış bir sanayi politikasına ihtiyaç vardır. Taymaz (2001:240), bu ihtiyacın, imalat sanayiinin ve bir bütün olarak ekonominin teknoloji geliştirme ve özümleme kapasitesinin geliştirilebilmesini amaçlayan bir kalkınma stratejisi; kapsamlı sanayi, teknoloji ve yenilik politikaları ve etkin bir şekilde çalışan ulusal yenilik sistemi ile karşılanabileceğini vurgulamaktadır. Türkiye'nin yaklaşık 70-80 yıllık yerli üretim tecrübesine karşın son on beş yıllık sürede yerliyenilikçi üretim ekonomisine ilişkin göstergelerindeki gelişmeler vurgulanan ihtiyacı ve gerçekleştirilmesi gereken dönüşümü destekler niteliktedir. Ek Tablo.1'den de izlenebileceği gibi Türkiye, yaklaşık 10 bin dolarlık kişi başına gelir düzeyi ile orta gelir tuzağı ve $\% 20-25^{\prime}$ ler düzeyinde seyreden sınai üretim payı ile erken-sanayisizleşme riski ile karşı karşıyadır. Bu riski belirgin kılan mevcut durum ve gelişmeler şu şekilde ifade edilebilir;

i. Türkiye'nin öğrenme sağlayabileceği teknoloji çeşitliliğini ve teknoloji düzeyini geliştirmesi gerekmektedir,

ii. İhraç edilen ürünler katma değeri düşük ürünlerdir ve bu ürünler gelişmiş ülkelerin ihraç ettiği ürünlere göre daha düşük teknolojili-daha ucuzdur,

iii. İthal edilen ürünlerin büyük kısmı ara malı niteliğindedir ve ülkenin sınai yapısı imalât sanayi yerine montaj sanayine odaklanmıştır,

iv. Uluslararası üretim zincirlerinde Türkiye yüksek katma değerli ürün ya da hizmetlerle varlık gösterememektedir,

v. Uluslararası rekabette piyasa payını arttırmak için kalite rekabeti yerine daha çok fiyat rekabeti önceliklidir,

vi. Sektörel ayrımı olmayan (ya da çok ayırdedici nitelikte olmayan) yatay teşvik politikalarının ağırlığını korumaktadır.

Mevcut durumu göz önünde bulundurması gereken yerli üretim odaklı sanayi politikasının başarısı, tamamen nasıl kurgulandığı ile ilişkili olarak ortaya çıkacaktır. Kurgunun başarıya ulaşabilmesi için stratejik sektörleri önceleyen ve bu yönde teknolojik öğrenmeyi ve ulusal teknolojik yetenek kapasitesinin arttıracak politikalar temel olmalıdır. Kıt kaynakların etkin bir biçimde kullanılması esasına odaklanmış bir sanayi politikasının şekillendirilmesi ve sürdürülebilir kılınması öncelikli adımlardan biri olmalıdır.

Enerji konusunda, özellikle Rusya ile yaşanan kriz sonrasında daha da belirginleşen dışa bağımlılık, yenilenebilir enerji yatırımlarının yetersizliği, cari açık 
sorunun varlığını koruyor olması, insan kaynağı odaklı kalkınma ve mesleki eğitim politikalarının eksikliği, kadınların işgücüne katılımındaki eksiklik gibi sorunlar da yerli üretim kapasite ve yeteneklerinin geliştirilmesini zorlaştırmaktadır. Türkiye gibi gelişmekte olan bir ülkenin ivedilikle beşeri, fiziki ve mali kaynaklarını en etkin biçimde kullanacağı, göreli olarak en öncelikli ve en önemli sektörlere yönelik politikalar üretmesi gerekmektedir. Bu sürecin etkin kılınması açısından Türkiye'nin öğrenme temelli bir teknoloji transferi politikasıyla teknolojik yetenek edinimine ihtiyaç vardır. Zira gelişmekte olan ülkelerin en önemli gündemi, yenilikçiliğin anahtarı olarak da ifade edilebilecek olan teknolojik öğrenme ve adaptasyondur.

Türkiye'de geç kalkınmanın ve yerli üretimin ekonomi politiği şekillendirilirken küresel gelişmeleri, yerel ve ulusal dinamikleri dikkate alan şu soruların göz önünde bulundurulması gerekmektedir:

i. Gerschenkron (1962) ve Vogel'e (1991) atıfla Türkiye'nin, tıpkı ikinci nesil geç kalkınan Asya Kaplanları arasından sıyrılmayı başarabilen Güney
Kore gibi, aradan sıyrılabilmesi, orta gelir tuzağını ve sanayisizleşme riskini bertaraf edebilen bir ülke olabilmesi için öncelikli sektörler hangileridir ve bu sektörlere yönelik alınması gereken tedbirler nelerdir?

ii. Bu süreçte Türkiye'nin ulusal yenilik ve ulusal öğrenme sistemleri yerel, ulusal dinamikleri dikkate alarak, bu kaynaklardan beslenerek toplumsal inanç ve kalkınma kararlılığı gösterecek şekilde nasıl yapılandırılmalıdır?

iii. Dünyanın gündeminde olan yeşil ekonomik kalkınma paradigmasını tamamlayıcı özellikteki yeşil sanayi politikalarının yapılandırılmakta olan sanayi politikasına içerilmesi nasıl sağlanmalıdır?

Türkiye, stratejik sektör önceliklendirmesini yapmak, öğrenme temelli teknolojik yetenek transferini iyi planlamak, incelenen bu soru(n) ları dikkate alan, yerli üretime odaklanmış politika tasarımını yapmak şartıyla, üçüncü nesil geç kalkınan ülkeler arasından ayrışmaya ve yükselen ekonomiler arasında yer almaya aday olabilir.

\section{KAYNAKLAR}

Akamatsu, K. (1961) A Theory of Unbalanced Growth in the World Economy. Weltwirtschaftliches Archiv, 86:196-217.

Akamatsu, K. (1962) A Historical Pattern of Economic Growth in Developing Countries. Journal of Developing Economies, 1(1):3-25.

Akkemik, K.A. (2009) Industrial Development in East Asia: A Comparative Look at Japan, Korea, Taiwan, and Singapore, Hackensack \& New Jersey: World Scientific.

Akkemik, K.A. (2012) "Dependence on Imported Inputs and Implications for Technology Transfer in Turkey". Designing Public Procurement Policies in Developing Countries: How to Foster Technology Transfer and Industrialization in the Global Economy. Yülek M.A., Travis K.T., USA:Springer

Amsden, A.H. (1989) Asia's Next Giant: South Korea and Late Industrialization, New York: Oxford University Press.

Atlı, A. (2013) "Değişen Çin ve Kriz Sonrası Dünya Düzenindeki Rolü", F.Şenses, Z.Öniş ve C. Bakır (eds) Ülke Deneyimleri Işığında Küresel Kriz ve Yeni Ekonomik Düzen, İstanbul: İletişim Yayınları

Aytaç, S.E. (2013) "Türkiye: Dengeli ve Sürdürülebilir Yüksek Büyüme Peşinde", F.Şenses, Z.Öniş ve C. Bakır (eds) Ülke Deneyimleri Işığında Küresel Kriz ve Yeni Ekonomik Düzen, İstanbul: İletişim Yayınları

Ballance, R.H., Ansari, J.A. ve Dinger, H.W. (1985) Uluslararası Ekonomi ve Sınaî Kalkınma. İstanbul: Çağlayan Kitabevi

Bilim Sanayi ve Teknoloji Bakanlığı (2011) Sanayi Strateji Belgesi (2011-2014), Ankara

Bilim Sanayi ve Teknoloji Bakanlığı (2015) Sanayi Strateji Belgesi (2015-2018), Ankara

Bilim Sanayi ve Teknoloji Bakanlığı (2015) Türkiye Sanayi Stratejisi Belgesi'ne (2011-2014) İlişkin Uygulama, İzleme ve Değerlendirme Raporları Serisi, Çevrimiçi Erişim Adresi: http://sanayipolitikalari. sanayi.gov.tr/Public/StrategieReports

Chang, HJ. (2009) Kalkınma Reçetelerinin Gerçek Yüzü. İstanbul: İletişim Yayınları

Chang, HJ.ve Grabel, I. (2004) Reclaiming Development: An Alternative Economic Policy Manual, London: Zed Book

Chopra, Aneesh (2014) Innovative State: How New Technologies Can Transform Government, NewYork: Atlantic Monthly Press 
Dervişoğlu, F.M. (2010) Nuri Demirağ: Türkiye'nin Havacılık Efsanesi, İstanbul: Ötüken Neşriyat

Elisa Elektronik (2014) Özel Elektronik Sistemler, Çevrimiçi Erişim Adresi: http://www.elisa.com.tr/ coezuemler/oezel-elektronik-sistemler, (01.08.2014)

Frank, A.G. (2010) Yeniden Doğu: Asya Çağında Küresel Ekonomi, Ankara: Imge Kitabevi Yayınları

Freeman, C. ve Louça, F. (2013) Zaman Akıp Giderken. İstanbul: İthaki Yayınları

Freeman, C. ve Soete, L. (1997) The Economics of Industrial Innovation. London and Washington: Pinter

Gerschenkron, A. (1962) Economic Backwardness in Historical Perspective, Belknap Press

Henderson, W. (1983) Friedrich List-Economist and Visionary, London. Frank Cass.

Johnson, C.A. (1982) MITI and the Japanese Miracle: The Growth of Industrial Policy, 1925-1975, Stanford: Stanford University Press.

Karagöl, E.T. (2014) "Kıtalar Arası Ekonomik İşbirliği: MIKTA", SETA-Perspektif, Sayı 62.

Karahan, H. (2014) 'Küresel Ekonomi 'Taze' Bir Soluk Ararken: Hoşçakal 'BRIC', Merhaba MINT", Seta-Analiz, Sayı: 100

Kayıı̧ı, F. (2011) "Sanayi Strateji Belgesi Üzerine Bir Değerlendirme" SETA Analiz, Sayı: 43

Kazgan, G. (2006) Tanzimattan 21. Yüzyıla Türkiye Ekonomisi, İstanbul: Bilgi Üniversitesi Yayınları

Kepenek, Y. ve Yentürk, N. (2001) Türkiye Ekonomisi, İstanbul: Remzi Yayınları

Koo, H. (1984) "The Political Economy oflncome Distrubution in South Korea: The Impact of State's Industrialization Policies", World Development, 12(10):1029-1037.

Kozlu, C. (2003) Türkiye Mucizesi için Vizyon Arayışları ve Asya Modelleri. İstanbul: Türkiye İş Bankası Kültür Yayınları

Kuruç, B. (2011) Mustafa Kemal Döneminde Ekonomi, İstanbul: Bilgi Üniversitesi Yayınları

Küçükkiremitçi, O. (2011) "Türkiye Sanayi Strateji Belgesi Temelinde İmalat Sanayinin Yapısal Analizi", Memleket Siyaset Yönetim Dergisi, 15:53-94.

Lall, S. (1994) "The East Asian Miracle: Does the Bell Toll for Industrial Strategy?", World Development, 20(4):645-654

Lall, S. (2009) "Sanayileşme Stratejisini Yeniden Düşünmek: Küreselleşme Çağında Devletin Rolü",
Fikret Şenses (eds.) Neoliberal Küreselleşme ve Kalkınma, İstanbul: İletişim Yayınları

List, F. (1841) The National System of Political Economy, London: Longmans

Mazzucato, Mariana (2013). The Entrepreneurial State: Debunking Public vs. Private Sector Myths, London: Anthem Press

Mah, J.S. (2007) "Industrial Policy and Economic Development: Korea's Experience", Journal of Economic Issues, 41(1), 77-92.

Mathews, J.A. (2002) "The Origins and Dynamics of Taiwan's R\&D Consortia", Research Policy, 31(4):633651.

NTVMSNBC (2000) "Türkiye'de Bilişimin Öyküsü", Çevrimiçi Erişim Adresi: http://arsiv.ntvmsnbc.com/ news/28088.asp, (21.08.2014)

Oğuz, Ş. (2013). "Kurumsalcı Bir Kurgu Olarak Kalkınmacı Devlet: Tarihsel ve Kuramsal Bir Eleştiri", Amme Idaresi Dergisi, 46(4): 107-128.

Okar, A. (2010) Türkiye'de Tayyarecilik, İstanbul: Yapı Kedi Kültür Yayınları

Orbay, Z. (2009) Türkiyesde Havacılık ve Uçak Yapımı, İstanbul: Türk Bilim Tarihi Kurumu

Öniş, Z. Ve Kutlay, M. (2013) "Rising Powers in a Changing Global Order: The Political Economy of Turkey in the Age of BRICs", Third World Quarterly, 34(8):1409-1426.

Öniş, Z.ve Şenses, F. (2009) "Küresel Dinamikler, Ülkeiçi Koalisyonlar ve Reaktif Devlet: Türkiyesnin Savaş Sonrası Kalkınmasında Önemli Politika Dönüşümleri", Fikret Şenses (eds.) Neoliberal Küreselleşme ve Kalkınma: Seçme Yazılar, İstanbul: İletişim Yayınları

Özel, I. (2013) "Krize Krizlerle Hazırlanmak: Meksika Ekonomisinde Süreklilik ve Dönüşüm", F.Şenses, Z.Öniş ve C. Bakır (eds) Ülke Deneyimleri Işığında Küresel Kriz ve Yeni Ekonomik Düzen, İstanbul: Illetişim Yayınları

Özilgen, M. (2011) Endüstrileşme Sürecinde Bilgi Birikiminin Öyküsü. İstanbul: Arkadaş Kitabevi

Özkan,Y.(1997) "AloıdaTürk Damgası", Çevrimiçi Erişim Adresi: http://www.milliyet.com.tr/11/08/1997/t/ ekonomi/alo.html, (21.07.2014)

Pamuk, Ş. (2014) Türkiye'nin 200 Yıllık iktisadi Tarihi, İstanbul: İş Bankası Kültür Yayınları

Rosenstein-Rodan, Paul. (1943) "Problems of Industrialization of Eastern and Southeastern Europe" Economic Journal. 53(210-211):202-2011 
Rudd, K. (2015) "G-20 ve Orta Ölçekli Devletlerin Küresel Ekonomi Yönetimindeki Önemi", Analist, 47:126-129.

Singh, A. (1994) "Openness and the Market-friendly Approach to Development: Learning the Right Lessons from Development Experience", World Development. 22(12):1811-1823.

Sönmez, A. (2003) Doğu Asya "Mucizesi" ve Bunalımı: Türkiye için Dersler. İstanbul: İstanbul Bilgi Üniversitesi Yayınları

Stiglitz, J. (1996) "Some Lessons from East Asian Miracle", World Bank Research Observer, 11(2):151177.

Suh, J.H. (2009) “Development Strategy and Evolution of Korea's Innovation System", Korea Development Institute (eds.) Models for National Technology and Innovation Capacity Development in Turkey. Korea: Korea Ministry of Strategy and Finance

Şahinkaya, S. (2011) "Türkiye Sanayi Strateji Belgesi (2014-2011) Üzerine Gözlemler", Memleket Siyaset Yönetim Dergisi, 15: 5-23.

Şenses, F. ve Taymaz, E. (2006) "Unutulan Bir Toplumsal Amaç: Sanayileşme Ne Oluyor? Ne Olmalı?", A.H. Köse, F. Şenses, ve E. Yeldan (eds) İktisadi Kalkınma, Kriz ve İstikrar, İstanbul: İletişim Yayınları

Şimşek, M. (2008) Yarım Kalan Devrim Rüyası, İstanbul: Alfa Yayınları

Taymaz, E. (2001) Ulusal Yenilik Sistemi: Türkiye İmalat Sanayinde Teknolojik Değişim ve Yenilik Süreçleri, Ankara:TÜBITAK-TTGV-SIS

Taymaz, E. ve Voyoda, E. (2012) “Marching to the Beat of a Late Drummer:Turkey's Experience of Neoliberal Industrialization since 1980", New Perspectives on Turkey, 47, 83-113.

Taymaz, E., Voyvoda, E. ve Yılmaz, K. (2011) Uluslararası Üretim Zincirlerinde Dönüşüm ve Türkiye'nin Konumu, İstanbul:TÜSIAD-Koç Üniversitesi Ekonomik Araştırma Forumu.

Tiryakioğlu, M. (2012) "Learning-based Technology Transfer Policies and Late Development: The South Korea Case", Murat Yülek ve Travis Taylor (eds) Designing Public Procurement Policy in Developing Countries, USA: Springer

Tiryakioğlu, M. (2015a) “Güney Kore'de Sanayi Politikasının Gelişimi: Öğrencilikten Öğretmenliğe Geçiş", K.A. Akkemik, ve S. Ünay (eds) Doğu Asya Ekonomi Politiği: Kalkınma, Siyaset, Jeostrateji. İstanbul: Boğaziçi Üniversitesi Yayınevi
Tiryakioğlu, M. (2015b) Teknolojik Yetenek Transferi: Türkiye İçin Bir Politika Arayışı, Ankara: Orion Yayınları

Tiryakioğlu, M. ve Yülek, M. (2015) “Developmentbased Public Procurement Policies: A Selective Survey of Literature, Cross Country Policy Experience and the Turkish Experience" Innovation: The European Journal of Social Science Research, 28(3):344-35.

TUSAŞ (2015) https://www.tai.com.tr/tr (01.09.2014)

TÜBITAK (2015) http://www.tubitak.gov.tr (01.09.2014)

Ünay, S. ve Kayıkçı, F. (2013) "Çok Kutuplu Küresel Ekonomik Düzen ve BRICS: Kriz Sonrası Sistemik Dönüşüm", F.Şenses, Z.Öniş ve C. Bakır (eds) Ülke Deneyimleri Işığında Küresel Kriz ve Yeni Ekonomik Düzen, İstanbul: İletişim Yayınları

Vogel, E. (1991) The Four Little Dragons: The Spread of Industrialization in East Asia, Cambridge: Harvard University Press.

Wade, R. (1990) Governing the Market - Economic Theory and the Role of Government in East Asian Industrialization, Princeton University Press.

Wade, R.H. (1996) "Japan, the World Bank, and the Art of Paradigm Maintenance: The East Asian Miracle in Political Perspective", New Left Review, I(217)

Watermeyer, R. (2012) “Linking Developmental Deliverables to Public Sector Contracts" Murat Yülek ve Travis Taylor (eds) Designing Public Procurement Policy in Developing Countries, USA: Springer

Wikipedia (2014) "Vecihi Hürkuş", http://tr.wikipedia. org/wiki/Vecihi_Hurkus, (01.09.2014)

World Bank (1993) The East Asian Miracle: Economic Growth and Public Policy, published for the World Bank by Oxford University Press.

Yalçın, O. (2013) Türk Hava Harp Sanayii Tarihi, İstanbul: İş Bankası Kültür Yayınları

Yanık, L. K. (2013) “Krizden Krize Rusya'da Iktisadi Değişim ve Dönüşüm", F.Şenses, Z.Öniş ve C. Bakır (eds) Ülke Deneyimleri Işığında Küresel Kriz ve Yeni Ekonomik Düzen, İstanbul: İletişim Yayınları

Yülek, M. (1998) Asya Kaplanları: Sanayi Politikaları ve Kalkınma, İstanbul: Alfa Yayınları.

Yülek, M. (2010a) "Teknolojik Gelişim: Learning, "Forgetting", "Un"learning, "Re"learnings", Dünya Gazetesi (22.03.2010)

Yülek, M. (2010b) "Teknolojik Gelişim: Learning"Forgetting" - "Un"learning - "Re"learning 2", Dünya Gazetesi (05.04.2010) 
Yülek, M. (2010c) “Teknolojik Gelişim: Learning"Forgetting"-"Un"learning-"Re"learning 3", Dünya Gazetesi, (12.04.2010)

Yülek, M. (2012) "Public Expenditure on Machinery and Equipment in Developing Countries: A Potential Technological Driver of Technological Development and Industrialization" Murat Yülek ve Travis Taylor (eds) Designing Public Procurement Policy in Developing Countries, USA: Springer

Yülek, M. ve Taylor, T. (2012) Designing Efficient Public Procurement Policies to Foster Technology Transfer and Development Capacity in Emerging Markets, USA: Springer 


\begin{tabular}{|c|c|c|c|c|c|c|c|c|c|c|c|c|c|c|c|c|c|c|c|c|c|}
\hline$\frac{d}{\pi}$ & $\stackrel{a}{\sim}$ & $\underset{\sim}{\sim}$ & $\approx$ & $\approx$ & \begin{tabular}{l}
0 \\
\multirow{2}{*}{} \\
\multirow{0}{0}{}
\end{tabular} & & $\begin{array}{l}\bar{N} \\
\stackrel{0}{0}\end{array}$ & 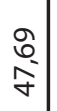 & $\begin{array}{l}\stackrel{2}{\tilde{\gamma}} \\
\bar{\gamma}\end{array}$ & $\begin{array}{l}\infty \\
\stackrel{0}{0} \\
\vdots\end{array}$ & & \begin{tabular}{l}
$\infty$ \\
$\infty$ \\
\multirow{\pm}{*}{}
\end{tabular} & $\mid \begin{array}{l}\hat{a} \\
\mathbf{N} \\
\hat{N}\end{array}$ & $\begin{array}{l}\hat{\alpha} \\
\bar{\epsilon}\end{array}$ & $\frac{\infty}{0}$ & & 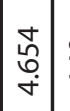 & $\underset{g}{\stackrel{g}{I}}$ & $\stackrel{\bar{\sigma}}{\check{\sigma}}$ & q & \\
\hline$\stackrel{m}{i}$ & $\stackrel{\sim}{\sim}$ & $\begin{array}{l}0 \\
\tilde{n} \\
\sim\end{array}$ & $\stackrel{⿱}{N}$ & 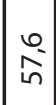 & $\begin{array}{l}\bar{\delta} \\
\text { o. } \\
0\end{array}$ & & $\begin{array}{c}\hat{N} \\
\text { O } \\
-\end{array}$ & 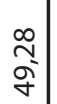 & $\begin{array}{l}8 \\
8 \\
\dot{q}\end{array}$ & $\begin{array}{l}m \\
\stackrel{m}{\circ} \\
0\end{array}$ & & $\begin{array}{l}\bar{\sigma} \\
\pm \\
-\end{array}$ & $\left|\begin{array}{l}m \\
0 \\
\tilde{n}\end{array}\right|$ & 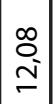 & $\begin{array}{l}0 \\
\vdots \\
0\end{array}$ & & \begin{tabular}{|l}
$\stackrel{q}{q}$ \\
$m$ \\
$\dot{\sigma}$
\end{tabular} \mid & nू & $\stackrel{\infty}{\bullet}$ & q & \\
\hline$\frac{\text { N }}{2}$ & $\bar{v}$ & \begin{tabular}{|l}
$\infty$ \\
$\stackrel{\sim}{\sim}$
\end{tabular} & 穴 & $\begin{array}{l}\stackrel{n}{2} \\
\text { in }\end{array}$ & \begin{tabular}{l}
$\circ$ \\
$\stackrel{0}{0}$ \\
\hdashline \\
\hdashline
\end{tabular} & & $\begin{array}{l}8 \\
0\end{array}$ & $\begin{array}{l}\bar{N} \\
\dot{\sim} \\
\mathbb{n}\end{array}$ & 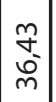 & $\begin{array}{c}m \\
m \\
o \\
o\end{array}$ & & $\begin{array}{l}\stackrel{ \pm}{m} \\
\underset{\sim}{-}\end{array}$ & $\left|\begin{array}{l}\tilde{n} \\
\hat{\kappa} \\
\kappa\end{array}\right|$ & $\begin{array}{l}\stackrel{\infty}{\underset{=}{=}} \\
=\end{array}$ & $\begin{array}{l}\bar{\sigma} \\
\dot{\sigma}\end{array}$ & & $\mid \begin{array}{c}\stackrel{8}{0} \\
m \\
+ \\
+\end{array}$ & $\stackrel{\infty}{\wedge}$ & $\begin{array}{l}\text { શ. } \\
\infty\end{array}$ & $\stackrel{\infty}{\sim}$ & \\
\hline $\bar{i}$ & $\begin{array}{l}\infty \\
\infty \\
\infty\end{array}$ & 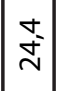 & $\infty_{\infty}^{\circ}$ & $\mid \begin{array}{l}m \\
i \\
i \\
i n\end{array}$ & $\mid \begin{array}{l}0 \\
0 \\
0 \\
0\end{array}$ & & $\begin{array}{l}\bar{n} \\
0 \\
-\end{array}$ & $\begin{array}{l}\stackrel{0}{2} \\
\text { ò } \\
\stackrel{n}{n}\end{array}$ & $\begin{array}{l}\stackrel{p}{1} \\
\infty \\
m \\
m\end{array}$ & $\begin{array}{l}\bar{\sigma} \\
\tilde{\sigma}\end{array}$ & & $\begin{array}{l}\text { f } \\
\stackrel{n}{n}\end{array}$ & $\left|\begin{array}{l}\infty \\
\infty \\
- \\
\kappa\end{array}\right|$ & $\begin{array}{c}\stackrel{N}{m} \\
\stackrel{N}{\sim}\end{array}$ & $\begin{array}{c}0 \\
\tilde{m} \\
0\end{array}$ & & $\left|\begin{array}{l}\mathfrak{\sigma} \\
o \\
m\end{array}\right|$ & $\stackrel{\Upsilon}{\simeq}$ & $\frac{ \pm}{\wedge}$ & in & \\
\hline$\frac{0}{2}$ & $\tilde{\sigma}$ & $\begin{array}{l}\stackrel{0}{0} \\
\stackrel{\sim}{\sim}\end{array}$ & $\underset{\infty}{+}$ & $\stackrel{2}{i}$ & $\begin{array}{l}\stackrel{n}{m} \\
\stackrel{0}{0} \\
\stackrel{0}{\circ}\end{array}$ & & $\begin{array}{l}\stackrel{m}{m} \\
\stackrel{0}{0}\end{array}$ & 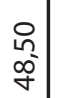 & $\begin{array}{l}\Omega \\
\hat{\sigma} \\
\tilde{m}\end{array}$ & \begin{tabular}{|c|}
0 \\
$m$ \\
0 \\
\end{tabular} & & 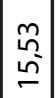 & $\mid \begin{array}{l}0 \\
0 \\
0 \\
0\end{array}$ & $\begin{array}{l}\stackrel{m}{m} \\
\stackrel{m}{n}\end{array}$ & స్ & & $\left|\begin{array}{c}\stackrel{2}{1} \\
\dot{m}\end{array}\right|$ & $\curvearrowright$ & 宫 & $m_{\infty}$ & \\
\hline : & $\begin{array}{l}\infty \\
\stackrel{f}{f}\end{array}$ & $\begin{array}{l}\hat{\mathfrak{v}} \\
\hat{\sim}\end{array}$ & $\underset{\infty}{m}$ & $\begin{array}{l}0 \\
0 \\
\text { in }\end{array}$ & 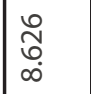 & & $\begin{array}{l}\infty \\
\infty \\
0 \\
0 \\
-\end{array}$ & $\begin{array}{l}0 \\
0 \\
0 \\
o \\
+\end{array}$ & $\left|\begin{array}{l}\infty \\
\infty \\
\infty \\
m \\
m\end{array}\right|$ & $\mid \begin{array}{c}n \\
\hat{n} \\
0 \\
0\end{array}$ & & $\begin{array}{l}\underset{n}{n} \\
\stackrel{n}{\sim}\end{array}$ & $\left|\begin{array}{l}\bar{\sigma} \\
0 \\
1\end{array}\right|$ & $\begin{array}{l}\hat{\jmath} \\
\dot{m}\end{array}$ & 守 & & 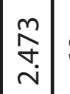 & 이 & $\overline{\mathrm{f}}$ & na & \\
\hline \begin{tabular}{l}
$\infty$ \\
$:$ \\
\hdashline
\end{tabular} & $\hat{0}$ & $\stackrel{ \pm}{ \pm}$ & $\stackrel{0}{\sim}$ & in & $\begin{array}{l}\stackrel{\rho}{2} \\
\hat{m} \\
0 \\
0\end{array}$ & & $\begin{array}{l}\hat{o} \\
\stackrel{i}{\sim}\end{array}$ & $\begin{array}{l}\stackrel{p}{m} \\
\frac{1}{n}\end{array}$ & $\mid \begin{array}{l}0 \\
\stackrel{0}{0} \\
\stackrel{0}{0}\end{array}$ & $\begin{array}{c}\hat{m} \\
\hat{0}\end{array}$ & & $\begin{array}{c}\hat{\infty} \\
\stackrel{n}{r}\end{array}$ & $\begin{array}{l} \pm \\
\dot{n} \\
\end{array}$ & 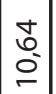 & \begin{tabular}{|c|}
$\tilde{n}$ \\
$\tilde{m}$ \\
$o$
\end{tabular} & & $\left|\begin{array}{c}\mathfrak{a} \\
\stackrel{n}{\sim} \\
\end{array}\right|$ & 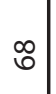 & $\stackrel{n}{\sim}$ & ஜ & \\
\hline ¿ें & F & $\stackrel{\infty}{\stackrel{\sim}{\sim}}$ & $\stackrel{0}{\sim}$ & 只 & $\mid \begin{array}{l}\frac{N}{m} \\
\bar{m}\end{array}$ & & 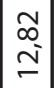 & $\begin{array}{l}20 \\
0 \\
b \\
\sigma\end{array}$ & $\begin{array}{c}m \\
\hat{o} \\
\dot{q}\end{array} \mid$ & $\begin{array}{c}\hat{a} \\
\tilde{m} \\
o\end{array}$ & & ๙َ. & $\mid \begin{array}{l}1 \\
0 \\
0 \\
0\end{array}$ & 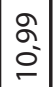 & $\begin{array}{l}q \\
\text { g } \\
0\end{array}$ & & 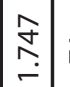 & $\pi$ & 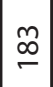 & $\stackrel{\stackrel{一}{m}}{\longrightarrow}$ & \\
\hline : & જે & $\stackrel{\infty}{\stackrel{\sim}{\sim}}$ & $\stackrel{m}{\infty}$ & 웃 & $\stackrel{\stackrel{0}{n}}{\stackrel{n}{N}}$ & & \begin{tabular}{l}
0 \\
\hdashline \\
$=$
\end{tabular} & $\frac{\infty}{\mathbb{f}}$ & $\frac{\infty}{\frac{f}{f}}$ & $\tilde{\sigma}$ & & $\begin{array}{l}\stackrel{n}{\hat{\sigma}} \\
\stackrel{0}{0}\end{array}$ & $\mid \begin{array}{l}\stackrel{0}{m} \\
\frac{m}{R}\end{array}$ & 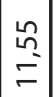 & $\begin{array}{l}0 \\
m \\
\text { on }\end{array}$ & & ๙̊ & $\bar{\lambda}$ & $\infty$ & $\mathcal{F}$ & \\
\hline ஜ̊ & $\stackrel{+}{\infty}$ & 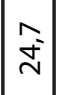 & চ̆ & 胥 & 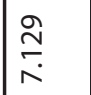 & & $\begin{array}{l}\infty \\
\infty \\
0 \\
0\end{array}$ & $\begin{array}{l}\underset{+}{\sigma} \\
-\end{array}$ & \begin{tabular}{l}
$\bar{\tau}$ \\
\multirow{f}{*}{}
\end{tabular} & $\mid \begin{array}{l}\infty \\
\stackrel{1}{0} \\
0\end{array}$ & & \begin{tabular}{l} 
\pm \\
\multirow{2}{*}{} \\
-2
\end{tabular} & $\begin{array}{l}\bar{\sigma} \\
\bar{g}\end{array}$ & $\begin{array}{l}\hat{\alpha} \\
=\end{array}$ & 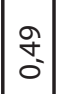 & & นૂ & $\stackrel{\llcorner}{\wedge}$ & in & $\frac{O}{\sim}$ & \\
\hline ర్ & ڤ̆ & $\stackrel{\overbrace{}}{\sim}$ & $\tilde{n}$ & $\begin{array}{l}m \\
\stackrel{n}{*}\end{array}$ & 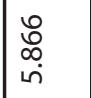 & & $\begin{array}{l}\stackrel{+}{m} \\
\stackrel{0}{0}\end{array}$ & $\begin{array}{l}\hat{0} \\
\dot{ \pm}\end{array}$ & 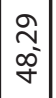 & $\begin{array}{c}0 \\
m \\
0 \\
\end{array}$ & & $\begin{array}{l}\stackrel{ \pm}{\infty} \\
\stackrel{-}{-}\end{array}$ & 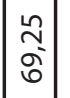 & $\begin{array}{l}\bar{J} \\
\stackrel{-}{ \pm}\end{array}$ & $\begin{array}{l}\bar{n} \\
0 \\
0\end{array}$ & & $\underset{\tilde{\vartheta}}{\tilde{\vartheta}}$ & 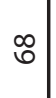 & ก & $\stackrel{\sim}{\mathbb{N}}$ & \\
\hline ֻ̊ํํ & $\stackrel{m}{n}$ & 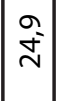 & gे & $\begin{array}{l}\mathcal{N} \\
\stackrel{5}{n}\end{array}$ & $\begin{array}{l}\stackrel{n}{2} \\
\hat{n} \\
+\end{array}$ & ঐे & $\frac{a}{\sigma}$ & $\begin{array}{l} \pm \\
\bar{m} \\
\dot{m}\end{array}$ & $\mid \begin{array}{l}8 \\
\vdots \\
\overline{-}\end{array}$ & 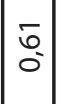 & ฐ & \begin{tabular}{|c|c|}
$\stackrel{m}{m}$ \\
$\stackrel{0}{-}$
\end{tabular} & $\begin{array}{l}m \\
\stackrel{n}{\kappa} \\
-1\end{array}$ & $\begin{array}{l}\hat{N} \\
\check{=}\end{array}$ & $\hat{0}$ & & 莳 & $\dddot{q}$ & N & 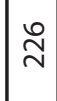 & \\
\hline ర్ & ชิ & 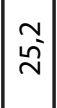 & $\begin{array}{l}m \\
\stackrel{0}{0}\end{array}$ & 只 & $\begin{array}{l}\stackrel{0}{2} \\
\hat{n} \\
m\end{array}$ & 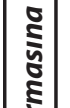 & $\stackrel{+}{\stackrel{*}{N}}$ & $\begin{array}{l}n \\
0 \\
0 \\
+ \\
+\end{array}$ & $\frac{\bar{n}}{\bar{n}}$ & $\begin{array}{l}\bar{\sigma} \\
\delta \\
\end{array}$ & 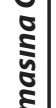 & 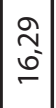 & 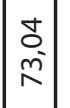 & $\begin{array}{l}\text { 오 } \\
\text { n. }\end{array}$ & $\cong$ & & 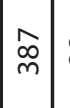 & $\begin{array}{l}\infty \\
\infty\end{array}$ & F & $\stackrel{g}{q}$ & \\
\hline ర్స & î & 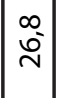 & $\begin{array}{l}\infty \\
\infty \\
\infty\end{array}$ & $\mid \begin{array}{l}n \\
\infty \\
\infty \\
n\end{array}$ & $\begin{array}{l}\hat{n} \\
\text { ñ } \\
\text { n. }\end{array}$ & 气ิ & $\begin{array}{l}\infty \\
\stackrel{\infty}{+} \\
\infty\end{array}$ & $\begin{array}{l}8 \\
\stackrel{0}{ } \\
\stackrel{y}{*}\end{array}$ & $\begin{array}{c}\bar{\pi} \\
\stackrel{\infty}{+}\end{array}$ & $\frac{n}{0}$ & 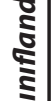 & $\mid \begin{array}{l}0 \\
\stackrel{6}{6} \\
-\end{array}$ & $\frac{a}{\bar{n}}$ & $\begin{array}{c}\bar{N} \\
\sigma\end{array}$ & $\mid \begin{array}{c}m \\
\infty \\
0 \\
o\end{array}$ & & $\begin{array}{l}\infty \\
\stackrel{\text { సे }}{ }\end{array}$ & 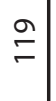 & $\bar{\tau}$ & $\hat{\tilde{n}}$ & \\
\hline ¿ั. & $\stackrel{\infty}{0}^{0}$ & $\stackrel{\Omega}{\curvearrowright}$ & $\overline{0}$ & $\begin{array}{l}0 \\
\text { Ln } \\
\text { nn }\end{array}$ & 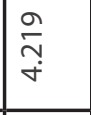 & $\frac{1}{\frac{1}{2}}$ & $\begin{array}{c}m \\
\stackrel{m}{\infty} \\
\\
\end{array}$ & $\begin{array}{l}\dot{U} \\
\stackrel{\sigma}{\sigma}\end{array}$ & $\begin{array}{l}0 \\
\tilde{m} \\
\stackrel{1}{n} \\
i n\end{array}$ & $\begin{array}{l}1 \\
0 \\
0\end{array}$ & $\frac{1}{\frac{1}{2}}$ & \begin{tabular}{|l|} 
\\
$\infty$ \\
$\infty$ \\
0 \\
\\
\end{tabular} & $\left|\begin{array}{l}0 \\
0 \\
0 \\
0\end{array}\right|$ & $\mid \begin{array}{l}\mathbf{N} \\
\stackrel{i}{\sim}\end{array}$ & $\begin{array}{c}\hat{n} \\
\tilde{n} \\
0\end{array}$ & & $\stackrel{\infty}{\sim}$ & $\mathfrak{f}$ & $\approx$ & $\stackrel{\hat{o}}{\sim}$ & 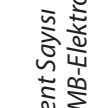 \\
\hline & 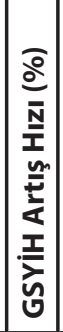 & 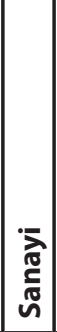 & 点 & 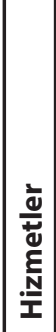 & 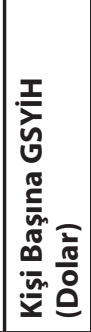 & 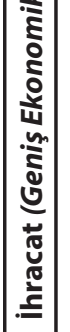 & 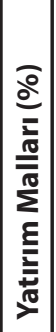 & 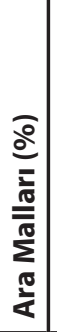 & 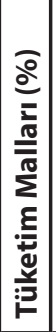 & $\mid$ & 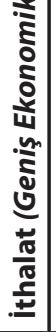 & 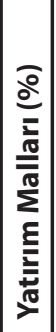 & 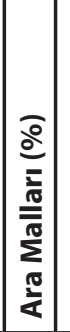 & 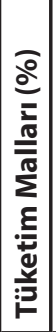 & 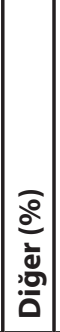 & 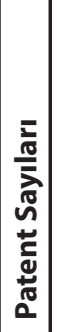 & 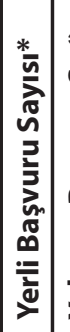 & 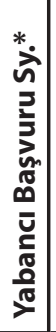 & 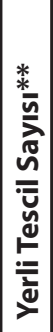 & 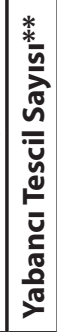 & 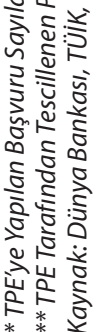 \\
\hline
\end{tabular}


